\title{
Leptin Resistance in the Ovary of Obese Mice is Associated with Profound Changes in the Transcriptome of Cumulus Cells
}

\author{
Karolina Wołodko ${ }^{\mathrm{a}}$ Edyta Walewska ${ }^{\mathrm{a}}$ Marek Adamowski ${ }^{\mathrm{a}}$ \\ Juan Castillo-Fernandez ${ }^{b}$ Gavin Kelsey ${ }^{b, c}$ António Galvão ${ }^{a, b, c}$
}

alnstitute of Animal Reproduction and Food Research of PAS, Department of Reproductive Immunology and Pathology, Olsztyn, Poland, 'Babraham Institute, Epigenetics Programme, Cambridge, UK,

'University of Cambridge, Centre for Trophoblast Research, Cambridge, UK

\author{
Key Words \\ Obesity • Cumulus cell $•$ Leptin $\cdot \operatorname{SOCS3} \cdot$ Transcriptome
}

\begin{abstract}
Background/Aims: Obesity is associated with infertility, decreased ovarian performance and lipotoxicity. However, little is known about the aetiology of these reproductive impairments. Here, we hypothesise that the majority of changes in ovarian physiology in diet-induced obesity (DIO) are a consequence of transcriptional changes downstream of altered leptin signalling. Therefore, we investigated the extent to which leptin signalling is altered in the ovary upon obesity with particular emphasis on effects on cumulus cells (CCs), the intimate functional companions of the oocyte. Furthermore, we used the pharmacological hyperleptinemic (LEPT) mouse model to compare transcriptional profiles to DIO. Methods: Mice were subjected to DIO for 4 and 16 weeks (wk) and leptin treatment for 16 days, to study effects in the ovary in components of leptin signalling at the transcript and protein levels, using Western blot, Realtime PCR and immunostaining. Furthermore, we used low-cell RNA sequencing to characterise changes in the transcriptome of CCs in these models. Results: In the DIO model, obesity led to establishment of ovarian leptin resistance after $16 \mathrm{wk}$ high fat diet (HFD), as evidenced by increases in the feedback regulator suppressor of cytokine signalling 3 (SOCS3) and decreases in the positive effectors phosphorylation of tyrosine 985 of leptin receptor (ObRbpTyr985) and Janus kinase 2 (pJAK2). Transcriptome analysis of the CCs revealed a complex response to DIO, with large numbers and distinct sets of genes deregulated at early and late stages of obesity; in addition, there was a striking correlation between body weight and global transcriptome profile of CCs. Further analysis indicated that the transcriptome profile in 4 wk HFD CCs resembled that of LEPT CCs, in the upregulation of cellular trafficking and impairment in cytoskeleton organisation. Conversely, after 16 wk HFD CCs showed expression changes indicative of augmented inflammatory responses, cell morphogenesis, and decreased metabolism and transport, mainly as a consequence of the physiological changes of obesity.
\end{abstract}




\section{Cellular Physiology Cell Physiol Biochem 2020;54:417-437 \\ \begin{tabular}{ll|l} 
DOl: 10.33594/000000228 & $\begin{array}{l}\text { O } 2020 \text { The Author(s). Published by } \\
\text { Cell Physiol Biochem Press GmbH\&Co, KG }\end{array}$
\end{tabular} \\ Wołodko et al.: Obesity-Induced Leptin Resistance Results in Altered Transcription in \\ Cumulus Cells}

Conclusion: Obesity leads to ovarian leptin resistance and major time-dependent changes in gene expression in CCs, which in early obesity may be caused by increased leptin signalling in the ovary, whereas in late obesity are likely to be a consequence of metabolic changes taking place in the obese mother.

\section{Introduction}

Obesity is considered one of the major public health challenges of modern times and has been linked to various comorbidities, such as metabolic syndrome, type 2 diabetes, cancer, stroke [1] and infertility [2]. Obese women have increased risk of menstrual dysfunctions and anovulation, pregnancy complications, and poor reproductive outcome [3]. In mouse models, obesity is characterised by lipid accumulation in the ovary and ensuing lipotoxicity [4] and oxidative stress [5]. Nonetheless, the exact mechanisms underlying ovarian pathogenesis in the course of obesity remain uncharacterised.

Leptin is a cytokine secreted by the adipose tissue (adipokine) [6]. Indeed, soon after the introduction to an obesogenic environment, large amounts of leptin can be found in the circulation [7], making this adipokine one of the early-onset obesity markers. Leptin controls food intake through its action at the central nervous system [8]; however, as a pleiotropic adipokine, leptin contributes to the regulation of numerous processes in the body, such as immune response [9] or angiogenesis [10]. Concerning the reproductive tract, leptin has been shown to control the neuroendocrine reproductive axis [11] and folliculogenesis [12]. Furthermore, leptin has been linked to ovulation [13] and embryo development [14]. Leptin is detected in most cell types in the murine ovary, with the highest staining intensity seen in the oocyte [15]. Nevertheless, no previous consideration has been made whether leptin signalling is dysregulated in the obese ovary. The leptin receptor b $(\mathrm{ObRb})$ is a type I cytokine receptor, which signals through the association with the tyrosine kinase Janus kinase 2 (JAK2). Upon leptin binding and dimerization of the receptor, JAK2 is recruited [16], mediating the phosphorylation of three conserved tyrosine residues on the intracellular domain of the receptor: tyrosine (Tyr) 985, Tyr1077 and Tyr1138. Subsequently, signalling molecules are recruited to these activated tyrosines [17] and, as a result, the signal transducer and activator of transcription (STAT) 5 and/or STAT3 are also phosphorylated and translocated into the nucleus, where they regulate transcription $[8,18]$. During sustained activation of $\mathrm{ObRb}$, the expression of both suppressor of cytokine signalling 3 (SOCS3) and tyrosineprotein phosphatase 1B (PTP1B) is initiated as a negative feedback response $[19,20]$. While PTP1B dephosphorylates JAK2, SOCS3 binds to receptor domains within JAK2 and Tyr985 and terminates signal transduction.

To date, little is known about the integrity of leptin signalling in the ovary during obesity progression, and its particular impact on the cumulus oophorous complex (COC). Cumulus cells (CCs) are vital regulators of oocyte growth and metabolism [21], controlling meiosis resumption [22], as well as the ovulation process itself [23]. Thus, a better knowledge of the pathophysiology of the events taking place in these cells in the course of obesity will allow us to understand the molecular mechanisms leading to impaired ovarian performance and infertility. Furthermore, the transcriptional signature of CCs has been used to predict oocyte competence or embryo quality [24, 25], demonstrating the importance of such references in assisted reproduction techniques. Here, we first characterise the establishment of leptin resistance in whole ovaries from diet induced obesity (DIO) mice fed for 4 and 16 weeks (wk). Subsequently, we analysed the transcriptome of CCs throughout obesity progression and identify temporally altered gene expression signatures. Finally, using a mouse model for pharmacological hyperleptinemia (LEPT), we pinpoint the transcriptional events mediated by increased leptin signalling in CCs in the early stages of obesity. 


\section{Cellular Physiology Cell Physiol Biochem 2020;54:417-437

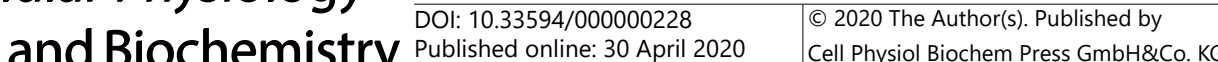 \\ Wołodko et al.: Obesity-Induced Leptin Resistance Results in Altered Transcription in \\ Cumulus Cells}

\section{Materials and Methods}

\section{Animal protocol}

Breeding pairs from mouse strains C57BL/6J (B6) and B6.Cg-Lep ${ }^{\mathrm{ob}} / \mathrm{J}(o b / o b)$ were obtained from the Jacksons Laboratory (The Jacksons Laboratory, Bar Harbour, Maine, USA). At 8 wk of age B6 animals were divided into 2 groups ( $n=12$ / group). In DIO, the control group was fed ad libitum chow diet (CD, $11 \%$ energy in kcal from fat, 5053, rodent diet 20, LabDiet IPS, London, UK), while the experimental group received high fat diet (HFD, 58\% energy in kcal from fat, AIN-76A 9G03, LabDiet IPS). Mice were maintained on the respective diet for 4 or $16 \mathrm{wk}$. Regarding the pharmacological hyperleptinemia protocol, $8 \mathrm{wk}$ old B6 female mice fed CD were divided into two groups (n=15/group): i) saline 16 days (d) (CONT); ii) leptin 16 d (Recombinant Mouse Leptin, GFM26, Cell Guidance Systems, Cambridge, UK). The animals were injected intraperitoneally twice a day, at $09: 00 \mathrm{~h}$ and $21: 00 \mathrm{~h}$ and total dosage of $100 \mu \mathrm{g} / \mathrm{day}$ of leptin was administrated. Concerning the $o b / o b$ model, mice were kept from weaning until twelve wk of age on CD. For all protocols, mice were housed with a $12 \mathrm{~h}$ light $/ 12 \mathrm{~h}$ dark cycle at room temperature $\left(23^{\circ} \mathrm{C}, \mathrm{RT}\right)$.

For phenotype characterisation of DIO, changes in body composition were monitored every 4 wk by nuclear magnetic resonance (NMR, Bruker, Rheinstetten, Germany), whereas in the LEPT model animals were phenotyped every three days. Body weight (BW), fat mass (FM), lean mass (LM), adiposity index (AI, fat mass/lean mass), and food intake (FI) were measured. For DIO and LEPT models vaginal cytology was done at 9:00 h, for twelve consecutive days. After vaginal lavage with saline, the smears were placed on clean glass slides and stained with Diff Quick Staining Set (Diff - Quick Color Kit, Rapid Staining Set, Medion Grifols Diagnostics AG, Duedingen, Switzerland), for cell identification as previously described [26]. The results were analysed for percent of time spent in oestrous stage (further explained in Supplementary Fig. 1J, 1K; Supplementary Fig. 2G - for all supplemental material see www.cellphysiolbiochem.com). All samples for mRNA, protein analysis and staining were collected at the oestrus stage.

A superovulation protocol was used for COC collection and further isolation of a pure population of CCs after removing the metaphase II (MII) oocytes. This developmental state of granulosa cells (GC) was preferred to ensure a tightly controlled level of progression. The animals were injected with pregnant mare's serum gonadotropin (PMSG, G4877, 5IU, Sigma Aldrich, Saint Louis, Missouri, USA) followed after 48 h by human chorionic gonadotropin (hCG, Chorulon, 5IU, MSD Animal Health, Boxmeer, Holland). Subsequently, $18 \mathrm{~h}$ after $\mathrm{hCG}$ injection the animals were sacrificed.

\section{Ovary collections}

Mice were sacrificed by cervical dislocation and the reproductive tracts collected and rinsed with phosphate buffered saline (PBS, $0.1 \mathrm{M}, \mathrm{pH}=7.4$ ). Ovaries were then removed from the genitalia and cleaned of adipose tissue. Ovaries were stored either in TRI Reagent (T9424, Sigma Aldrich) for mRNA, or radioimmunoprecipitation assay buffer (RIPA, 89901, Thermo Fisher Scientific, Waltham, Massachusetts, USA) supplemented with protease inhibitor cocktail (PIC, P8340, Sigma Aldrich), phenylmethylsulfonyl fluoride (PMSF, P7626, Sigma Aldrich) and phosphatase inhibitor (88667, Thermo Fisher Scientific), for protein analysis. Samples were stored at $-80^{\circ} \mathrm{C}$, except for the analysis of phosphorylated proteins, in which samples were isolated immediately after sacrificing the animals.

\section{Ovarian cell isolation protocol}

For theca and stroma enriched (TC) fraction collection, immediately after culling the animals, ovaries were transferred to Dulbecco's modified Eagle's medium (DMEM, D/F medium; 1:1 (v/v), D-8900, Sigma Aldrich) with 3\% bovine serum albumin (BSA, 735078, Roche Diagnostics GmbH, Mannheim, Germany), 20 $\mu \mathrm{g} / \mathrm{ml}$ gentamicin (G1397, Sigma Aldrich) and $250 \mu \mathrm{g} / \mathrm{ml}$ amphotericin (A2942, Sigma Aldrich). For the TC fraction, ovaries were punctured with a 16 gauge needle as described before [27]. Briefly, after removing GC and oocytes, the remaining tissue was washed twice with media and stored in TRI Reagent for mRNA analysis ( $\mathrm{n}=8$ /group). For CCs, after superovulating the animals, COCs were retrieved from oviducts, and further digested with hyaluronidase (H3506, $400 \mu \mathrm{g} / \mathrm{ml}$, Sigma Aldrich). After removing the oocytes, a total of approximately 50 pure CCs were collected from one individual animal from either 4 wk or 16 wk DIO ( $n=5 /$ condition), as well as the $16 \mathrm{~d}$ LEPT ( $\mathrm{n}=$ at least 3/ condition) protocol. 


\section{Cellular Physiology Cell Physiol Biochem 2020;54:417-437

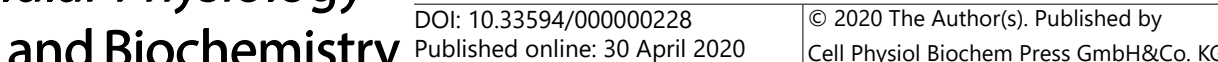 \\ Wołodko et al.: Obesity-Induced Leptin Resistance Results in Altered Transcription in \\ Cumulus Cells}

\section{RNA isolation and cDNA synthesis}

For mRNA extraction, either whole ovaries or TC fraction were collected from mice in oestrus stage, placed in $1 \mathrm{ml}$ of TRI Reagent in $1.5 \mathrm{ml}$ eppendorf tubes ( $\mathrm{n}=8$ / group) and mechanically disrupted with a lancet. The suspension was pipetted up and down vigorously and incubated for 5 minutes ( $\mathrm{min}$ ) at RT. After centrifugation $\left(9400 \mathrm{~g}, 4^{\circ} \mathrm{C}, 15 \mathrm{~min}\right)$, the supernatant was transferred to a fresh tube and thoroughly mixed with $100 \mu \mathrm{l}$ of 1-Bromo-3-chloropropane (BCP, BP151, Molecular Research Centre, Cincinnati, Ohio, USA), followed by incubation at RT for $10 \mathrm{~min}$. Subsequently, samples were centrifuged $\left(13500 \mathrm{~g}, 4^{\circ} \mathrm{C}, 15 \mathrm{~min}\right)$ and the aqueous phase transferred to a new tube, before being mixed with an equal volume of isopropanol and incubated at $-80^{\circ} \mathrm{C}$ for $60 \mathrm{~min}$. Another centrifugation $\left(20000 \mathrm{~g}, 4^{\circ} \mathrm{C}, 15 \mathrm{~min}\right)$ to pellet down the RNA, which was then washed three times with $75 \%$ ethanol and incubated overnight at $-80^{\circ} \mathrm{C}$. Next day, samples were centrifuged $\left(20000 \mathrm{~g}, 4^{\circ} \mathrm{C}, 15 \mathrm{~min}\right)$ and the RNA pellet dried and resuspended in $20 \mu \mathrm{l}$ of RNAse free water (W4502, Sigma Aldrich), supplemented with RNAse Inhibitor (RiboProtect, RT35, BLIRT, Gdańsk, Poland). Finally, RNA quality and concentration were assessed with NanoDrop. Absorbance ratio at $260 \mathrm{~nm}$ and 280 $\mathrm{nm}$ (A260/A280) was determined and the quality and concentration of isolated mRNA confirmed.

A total of $1 \mu \mathrm{g}$ of RNA was reversely transcribed using Maxima First Strand cDNA Synthesis Kit for Real-time polymerase chain reaction (PCR) (K1642, Thermo Scientific) according to the manufacturer's instructions. The cDNA was stored at $-20^{\circ} \mathrm{C}$ until the real-time PCR was carried out.

\section{Real-time polymerase chain reaction}

Real-time PCR was performed in a 7900 Real-Time PCR System (Applied Biosystems, Warrington, UK) using Maxima SYBR Green/ROX qPCR Master Mix (K0223, Thermo Scientific). Primers were designed using Primer 3.0 v.0.4.0. software [28], based on gene sequences from GeneBank (NCBI), as described before [29]. All primers were synthesised by Sigma Aldrich. Primer sequences, expected PCR products length, and GeneBank accession numbers are reported in Table 1 . The total reaction volume was $12 \mu \mathrm{l}$, containing $4 \mu \mathrm{l}$

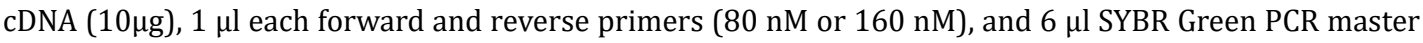
mix. Real-time PCR was carried out as follows: initial denaturation $\left(10 \mathrm{~min}\right.$ at $\left.95^{\circ} \mathrm{C}\right)$, followed by 45 cycles of denaturation $\left(15 \mathrm{~s}\right.$ at $\left.95^{\circ} \mathrm{C}\right)$ and annealing $\left(1 \mathrm{~min}\right.$ at $\left.60^{\circ} \mathrm{C}\right)$. After each PCR, melting curves were obtained by stepwise increases in temperature from 60 to $95^{\circ} \mathrm{C}$ to ensure single product amplification. In each realtime assay, both the target gene and a housekeeping gene (HKG) - Ribosomal Protein L37 (Rpl37, primers in Table 1) or Eukaryotic Translation Initiation Factor 5 A (Eif5a, primers in Table 1) - were run simultaneously and reactions were carried out in duplicate wells in a 384-well optical reaction plate (4306737, Applied Biosystems). The HKG selection was performed with NormFinder, in each experimental group. Real-time PCR results were analysed with the Real-time PCR Miner algorithm [30].

\section{Western blot}

Protein expression was assessed by western blot ( $\mathrm{n}=5$ /group). Ovaries from mice in oestrus stage were collected into RIPA supplemented with inhibitors and mechanically disrupted with a lancet. Then, lysates were incubated for one hour on ice, with mixing every $15 \mathrm{~min}$. Subsequently, samples were centrifuged $\left(20000 \mathrm{~g}, 4^{\circ} \mathrm{C}, 15 \mathrm{~min}\right)$ and the supernatant was collected and stored at $-80^{\circ} \mathrm{C}$ until the analysis. The protein concentration was assessed using bicinchoninic acid assay (BCA, BCA1-1KT, Sigma Aldrich). A total of $10-40 \mu \mathrm{g}$ of protein was loaded on $8-14 \%$ acrylamide gel, and after electrophoresis proteins were transferred to polyvinylidene difluoride (PVDF) or nitrocellulose membrane depending on the antibodies to be used. Membranes were blocked in 5\% BSA (A2153, Sigma Aldrich) and incubated with primary antibodies $(\mathrm{AB})$ overnight at $4^{\circ} \mathrm{C}$. Leptin receptor and its phosphorylated domains were evaluated using the following antibodies: mouse monoclonal (MM) against leptin receptor (ObR; 1:500, sc-8391, Santa Cruz Biotechnology, Dallas, Texas, USA), goat polyclonal (GP) against phosphorylated Tyr $985 \mathrm{ObRb}$ (pTyr9850bRb; 1:500, sc-16419, Santa Cruz Biotechnology), rabbit polyclonal (RP) against phosphorylated Tyr 1077 ObRb (pTyr10770bR; 1:500, 07-1317, Merck Millipore, Burlington, Vermont, USA), GP against phosphorylated Tyr 1138 ObRb (pTyr11380bRb; 1:500, sc-16421, Santa Cruz Biotechnology). The expression of other leptin signalling pathway components was assessed using the following antibodies: RP against JAK2 (1:200, sc-294, Santa Cruz Biotechnology), RP against phosphorylated Tyr 1007/1008 JAK2 (pJAK2; 1:200, sc-16566-R, Santa Cruz Biotechnology), RP against STAT3 (1:200, sc-482, Santa Cruz Biotechnology), MM against phosphorylated Tyr 705 pSTAT3 (1:200, sc-8059, Santa Cruz Biotechnology), RP against STAT5 (1:200, sc-835, Santa Cruz Biotechnology), MM against phosphorylated Tyr 694/699 
Cell Physiol Biochem 2020;54:417-437

\begin{tabular}{l|l}
\hline DOI: $10.33594 / 000000228$ & (c) 2020 The Author(s). Published by
\end{tabular}

Published online: 30 April $2020 \quad$ Cell Physiol Biochem Press GmbH\&Co. KG

Wołodko et al.: Obesity-Induced Leptin Resistance Results in Altered Transcription in

Cumulus Cells

Table 1. Specific primer sequences used for quantitative real-time PCR

\begin{tabular}{|c|c|c|c|c|c|}
\hline $\begin{array}{l}\text { Functional } \\
\text { pathway }\end{array}$ & Gene name & $\begin{array}{c}\text { Gene } \\
\text { symbol }\end{array}$ & $\begin{array}{c}\text { GeneBank } \\
\text { Accession no. }\end{array}$ & Sequences 5'-3' & $\begin{array}{l}\text { Length } \\
\text { (base } \\
\text { pair) }\end{array}$ \\
\hline \multirow{18}{*}{$\begin{array}{l}\text { Leptin } \\
\text { signalling }\end{array}$} & \multirow[b]{2}{*}{ Leptin receptor } & \multirow[b]{2}{*}{ Obrb } & \multirow[b]{2}{*}{ NM_146146.2 } & CCTCCAGGAGAGATGCTCACAC & \multirow[b]{2}{*}{111} \\
\hline & & & & TGACTGTGCGTGGAACAGGT & \\
\hline & \multirow{2}{*}{ Janus kinase 2} & \multirow{2}{*}{ Jak2 } & \multirow{2}{*}{ NM_001048177.2 } & GGTGTTTCACAAAATCAGGAATG & \multirow{2}{*}{119} \\
\hline & & & & TGTGCAGTTGACCATAATCTCC & \\
\hline & \multirow{2}{*}{$\begin{array}{l}\text { SH2B adaptor } \\
\text { protein } 1\end{array}$} & \multirow{2}{*}{$\operatorname{Sh} 2 b$} & \multirow{2}{*}{ NM_001289539.1 } & GGACCCAGCGAGAGTAACGA & \multirow{2}{*}{101} \\
\hline & & & & GCAGCAATGGAGGCAGAACT & \\
\hline & \multirow{2}{*}{$\begin{array}{l}\text { Signal transducer } \\
\text { and activator of } \\
\text { transcription } 3\end{array}$} & \multirow{2}{*}{ Stat3 } & \multirow{2}{*}{ NM_011486.5 } & CGATGCCTGTGGGAAGAGTC & \multirow{2}{*}{97} \\
\hline & & & & CTGTCACTACGGCGGCTGTT & \\
\hline & \multirow{2}{*}{$\begin{array}{l}\text { Signal transducer } \\
\text { and activator of } \\
\text { transcription } 5 \mathrm{~A}\end{array}$} & \multirow{2}{*}{ Stat5a } & \multirow{2}{*}{ NM_001164062.1 } & GGGACAATGCCTTTGCTGAG & \multirow{2}{*}{123} \\
\hline & & & & AGCCCCGGTTGCTCTGTACT & \\
\hline & \multirow{2}{*}{$\begin{array}{l}\text { Signal transducer } \\
\text { and activator of } \\
\text { transcription 5B }\end{array}$} & \multirow{2}{*}{ Stat5b } & \multirow{2}{*}{ NM_001113563.2 } & CAGGACAACAATGCCACAGC & \multirow{2}{*}{172} \\
\hline & & & & TTTGGCCGATCAGGAAACAC & \\
\hline & \multirow{2}{*}{$\begin{array}{l}\text { Protein tyrosine } \\
\text { phosphatase, non- } \\
\text { receptor type } 2\end{array}$} & \multirow{2}{*}{ Ptpn2 } & \multirow{2}{*}{ NM_008977.3 } & CGCTCTGGCACCTTCTCTCT & \multirow{2}{*}{283} \\
\hline & & & & GGAAAGGCAGGATCTCTCGA & \\
\hline & \multirow{2}{*}{$\begin{array}{l}\text { Protein tyrosine } \\
\text { phosphatase non } \\
\text { receptor type } 1\end{array}$} & \multirow{2}{*}{ Ptp1b } & \multirow{2}{*}{ NM_011201.3 } & TGGCCACAGCAAGAAGAAAA & \multirow{2}{*}{151} \\
\hline & & & & GGAAAGGCAGGATCTCTCGA & \\
\hline & \multirow{2}{*}{$\begin{array}{c}\text { Suppressor of } \\
\text { cytokine signaling } 3\end{array}$} & \multirow{2}{*}{ Socs3 } & NM 00770 & GCGAGAAGATTCCGCTGGTA & 151 \\
\hline & & & NAIN_- & TACTGATCCAGGAACTCCCGA & 101 \\
\hline & Ribosomal protein & Rnl37 & NM 0260693 & CTGGTCGGATGAGGCACCTA & 108 \\
\hline Reference & & & & AAGAACTGGATGCTGCGACA & \\
\hline genes & Eukaryotic & & & ССТCAGCСАССТТСССААТ & \\
\hline & factor $5 \mathrm{~A}$ & Ell5a & NIM_001106594.1 & AAATGTCAATGCCAACCAGATG & 150 \\
\hline
\end{tabular}

pSTAT5 (1:200, sc-81524, Santa Cruz Biotechnology), GP against PTP1B (1:200, sc-1718, Santa Cruz Biotechnology), MM against SOCS3 (1:500, sc-51699, Santa Cruz Biotechnology) in cell lysates. The results were normalized with $\beta$-actin (1:10000, MM, A2228, Sigma-Aldrich). All antibodies specifications are summarised in Table 2. Proteins were detected after incubation of the membranes with secondary GP antirabbit alkaline phosphatase-conjugated antibody (1:30000, A3687, Sigma Aldrich), GP anti-mouse alkaline phosphatase-conjugated antibody (1:20000, 31321, Thermo Scientific), RP anti-goat alkaline phosphataseconjugated (1:30000, A4187, Sigma Aldrich), or RP anti-goat horseradish peroxidase- conjugated antibody (1:75000, A50-100P, Bethyl, Montgomery, Alabama, USA) for $2 \mathrm{~h}$ at RT. Immune complexes were visualized using the alkaline phosphatase visualization procedure or ECL substrate visualization. Blots were scanned in a Molecular Imager VersaDoc MP 4000 System (BioRad, Hercules, California, USA) and specific bands quantified using ImageLab Software (BioRad). Finally, band density for each protein was normalised against $\beta$-actin.

\section{Immunohistochemistry and immunofluorescent staining}

Ovaries collected from mice in oestrus stage ( $\mathrm{n}=3$ /group) were fixed in $4 \%$ neutral phosphatebuffered formalin (NBF, 432173427, Poch, Gliwice, Poland) at $4^{\circ} \mathrm{C}$ for $24 \mathrm{~h}$, and subsequently dehydrated in ethanol. Paraffin embedded ovarian tissues were sectioned into $5 \mu \mathrm{m}$ slices. For antigen retrieval, sections were heated in citrate buffer $(10 \mathrm{mM}, \mathrm{pH}=6.0)$. Tissue was incubated in blocking solution (ab64261, Abcam, Cambridge, UK) for $1 \mathrm{~h}$ at RT and primary RP anti-SOCS3 antibody (1:1000, ab16030, Abcam) or primary 


\section{Cellular Physiology Cell Physiol Biochem 2020;54:417-437 \begin{tabular}{ll|l} 
and Biochemisty $10.33594 / 000000228$ & DO 2020 The Author(s). Published by \\
Published online: 30 April 2020 & Cell Physiol Biochem Press GmbH\&Co. KG
\end{tabular} \\ Wołodko et al.: Obesity-Induced Leptin Resistance Results in Altered Transcription in \\ Cumulus Cells}

Table 2. Specification of antibodies used for Western blot

\begin{tabular}{|c|c|c|}
\hline Antibody name and specificity & Company, Cat no, RRID no & $\begin{array}{c}\text { Antibody } \\
\text { dilution }\end{array}$ \\
\hline Mouse monoclonal against leptin receptor (ObR) & $\begin{array}{c}\text { Santa Cruz Biotechnology Cat\# sc- } \\
\text { 8391, RRID:AB_627882 }\end{array}$ & $1: 500$ \\
\hline $\begin{array}{l}\text { Goat polyclonal against phosphorylated Tyr-985 of } \\
\text { leptin receptor (p-ObR Tyr985) }\end{array}$ & $\begin{array}{c}\text { Santa Cruz Biotechnology Cat\# sc- } \\
\text { 16419, RRID:AB_2234640 }\end{array}$ & $1: 500$ \\
\hline $\begin{array}{l}\text { Rabbit polyclonal against phosphorylated Tyr } 1077 \text { ObR } \\
\text { (p-ObR Tyr1077) }\end{array}$ & $\begin{array}{l}\text { Millipore Cat\# 07-1317, } \\
\text { RRID:AB_1977322 }\end{array}$ & $1: 500$ \\
\hline $\begin{array}{l}\text { Goat polyclonal against phosphorylated Tyr } 1138 \text { ObR } \\
\text { (p-ObR Tyr1138) }\end{array}$ & $\begin{array}{c}\text { Santa Cruz Biotechnology Cat\# sc- } \\
\text { 16421, RRID:AB_2288076 }\end{array}$ & $1: 500$ \\
\hline Rabbit polyclonal against Janus kinase 2 (Jak2) & $\begin{array}{l}\text { Santa Cruz Biotechnology Cat\# sc- } \\
\text { 294, RRID:AB_631854 }\end{array}$ & $1: 200$ \\
\hline $\begin{array}{l}\text { Rabbit polyclonal against phosphorylated Tyr } \\
\text { 1007/1008 Jak2 (pJak2) }\end{array}$ & $\begin{array}{l}\text { Santa Cruz Biotechnology Cat\# sc- } \\
\text { 16566-R, RRID:AB_653287 }\end{array}$ & $1: 200$ \\
\hline $\begin{array}{l}\text { Rabbit polyclonal against Signal transducer and } \\
\text { activator of transcription } 3 \text { (STAT3) }\end{array}$ & $\begin{array}{l}\text { Santa Cruz Biotechnology Cat\# sc- } \\
\text { 482, RRID:AB_632440 }\end{array}$ & $1: 200$ \\
\hline $\begin{array}{l}\text { Mouse monoclonal against phosphorylated Tyr } 705 \\
\text { Signal transducer and activator of transcription } 3 \\
\text { (pSTAT3) }\end{array}$ & $\begin{array}{l}\text { Santa Cruz Biotechnology Cat\# sc- } \\
\text { 8059, RRID:AB_628292 }\end{array}$ & $1: 200$ \\
\hline $\begin{array}{l}\text { Rabbit polyclonal against Signal transducer and } \\
\text { activator of transcription } 5 \text { (STAT5) }\end{array}$ & $\begin{array}{l}\text { Santa Cruz Biotechnology Cat\# sc- } \\
\text { 835, RRID:AB_632446 }\end{array}$ & $1: 200$ \\
\hline $\begin{array}{l}\text { Mouse monoclonal against phosphorylated Tyr 694/699 } \\
\text { Signal transducer and activator of transcription } 5 \\
\text { (pSTAT5) }\end{array}$ & $\begin{array}{l}\text { Santa Cruz Biotechnology Cat\# sc- } \\
\text { 81524, RRID:AB_1129712 }\end{array}$ & $1: 200$ \\
\hline $\begin{array}{l}\text { Goat polyclonal against Protein tyrosine phosphatase 1B } \\
\text { (PTP1B) }\end{array}$ & $\begin{array}{l}\text { Santa Cruz Biotechnology Cat\# sc- } \\
\text { 1718, RRID:AB_2174942 }\end{array}$ & $1: 200$ \\
\hline $\begin{array}{l}\text { Mouse monoclonal against Suppressor of cytokine } \\
\text { signalling } 3 \text { (SOCS3) }\end{array}$ & $\begin{array}{l}\text { Santa Cruz Biotechnology Cat\# sc- } \\
\text { 51699, RRID:AB_630243 }\end{array}$ & $1: 500$ \\
\hline Mouse monoclonal against $\beta$-actin & $\begin{array}{c}\text { Sigma Aldrich Cat\# A2228, } \\
\text { RRID:AB_476697 }\end{array}$ & 1:10000 \\
\hline
\end{tabular}

RP anti-PTP1B antibody (1:500, ab189179, Abcam) added overnight at $4^{\circ} \mathrm{C}$. The negative control sections were incubated with RP anti-immunoglobulin G (IgG, ab37415, Abcam) or without primary antibody. The primary antibody complexes were detected after incubating the tissue with biotinylated goat anti-rabbit IgG (H+L) (ab64261, Abcam) for $60 \mathrm{~min}$, and streptavidin peroxidase for $40 \mathrm{~min}$. Staining was evident after $15 \mathrm{~s}$ incubation in 3,3-diaminobenzidine (DAB) peroxidase substrate solution (Rabbit-specific HRP/DAB (ABC) Detection IHC Kit, ab64261, Abcam). Subsequently, samples were counterstained with haematoxylin (MHS16, Sigma Aldrich) and mounted. Sections were examined using Axio Observer Systems Z1 microscope (Carl Zeiss Microscopy GmbH, Hannover, Germany) and Zeiss ZEN 2.5 lite Microscope Software (Carl Zeiss, Germany). For immunofluorescence (IF), $5 \mu \mathrm{m}$ sections were deparaffinised and rehydrated in an ethanol series. Next, tissues were permeabilised in 0.3\% Triton X-100 (T8787, Sigma Aldrich), followed by antigen retrieval in citrate buffer $(10 \mathrm{mM}, \mathrm{pH}=6.0)$ for $40 \mathrm{~min}$ at $90^{\circ} \mathrm{C}$ and blocking in $2 \% \mathrm{BSA}$ (A2153, Sigma Aldrich) with 0,3 M glycine (G8898, Sigma Aldrich) in PBS-0.1\% Tween 20 (P7949, Sigma Aldrich) (PBST) solution. Sections were then incubated with 0.3\% Sudan Black (199664, Sigma Aldrich) in 70\% ethanol for 10 min at RT, followed by washes in PBST. Slides were subsequently incubated with RP anti-SOCS3 antibody (1:200, ab16030, Abcam) overnight at $4^{\circ} \mathrm{C}$. The negative control sections were incubated with RP anti-IgG (1:200) as before, or without primary antibody. On the next day slides were washed in PBST, followed by incubation with cyanine 3 (Cy3)- donkey polyclonal anti-rabbit IgG (H+L) (711-165-152, Jackson ImmunoReserach, Cambridgeshire, UK), and a series of washes in PBST. Finally, slides were covered with a drop of Prolong Gold medium with diamidino-2-phenylindole (DAPI) and sealed with cover slips. Images were captured using $40 \mathrm{x} / 1.2 \mathrm{~A}$ or $63 \mathrm{x} / 1.4 \mathrm{~A}$ oil immersion objectives on a LSM800 confocal microscope (Carl Zeiss, Germany). 


\section{Cellular Physiology Cell Physiol Biochem 2020;54:417-437 \begin{tabular}{l|l} 
DOI: 10.33594/000000228 & (c) 2020 The Author(s). Published by
\end{tabular} \\ Wołodko et al.: Obesity-Induced Leptin Resistance Results in Altered Transcription in \\ Cumulus Cells}

Enzyme-linked immunosorbent assay

Animals in oestrus were sacrificed ( $n=8$ /group) and blood samples collected after puncturing the heart. Blood samples were centrifuged $\left(1800 \mathrm{~g}, 4^{\circ} \mathrm{C}, 10 \mathrm{~min}\right)$ and plasma stored at $-80^{\circ} \mathrm{C}$. Levels of circulating leptin and insulin were assessed with enzyme-linked immunosorbent assay (ELISA) kit, according to the manufacturer's instructions (Mouse Leptin ELISA Kit, 90030; Crystal Chem, Zaandam, Netherlands; Rat/ Mouse Insulin ELISA Kit, EZRMI-13K; Merck Millipore). The intra- and interassay coefficients of variation (CVs) were as follows: for Leptin ELISA kit $<10 \%$ both and for Insulin ELISA kit 8.35\% and 17.9\%, respectively. To determine SOCS3 in ovarian extracts, ELISA test was used (ELISA KIT for SOCS3; SEB684Mu, Cloud- Clone, Texas, USA). Briefly, the tissue was minced in lysis buffer ( $n=8 /$ group), centrifuged (10000 $\mathrm{g}, 4^{\circ} \mathrm{C}, 5 \mathrm{~min}$ ) and protein concentration in the lysate determined with BCA test. All tests and assessments were performed according to the manufacturer's instructions.

\section{RNA-seq library generation}

Once the 16 wk HFD group presented divergence in BW gain, we identified 3 animals with less than $33 \mathrm{~g}$ of body weight that we designated as HFD low gainers (HFDLG) and excluded them from the regular HFD group for the further description of differently expressed genes (DEGs) between CD and HFD. CCs were collected into RLT buffer (1053393, Qiagen, Hilden, Germany) and kept at $-80^{\circ} \mathrm{C}$ until library generation. Subsequently, RNA sequencing (RNA-seq) libraries were prepared following a previously described protocol [31, 32], with minor changes. Briefly, mRNA was captured using Smart-seq2 oligo-dT pre-annealed to magnetic beads (MyOne C1, Invitrogen, Carlsbad, California, USA). The beads were resuspended in $10 \mu \mathrm{l}$ of reverse transcriptase mix (100 U, SuperScript II, Invitrogen; 10 U, RNAsin, Promega, Madison, Wisconsin, USA), $1 \times$ Superscript II First-Strand Buffer, $2.5 \mathrm{mM}$ ditiotreitol (DTT, Invitrogen), $1 \mathrm{M}$ betaine (Sigma Aldrich), $9 \mathrm{mM}$ magnesium chloride ( $\mathrm{MgCl}_{2}$, Invitrogen), $1 \mu \mathrm{M}$ Template-Switching Oligo (Exiqon, Vedbaek, Denmark), $1 \mathrm{mM}$ deoxyribonucleotide triphosphate (dNTP) mix (Roche) and incubated for $60 \mathrm{~min}$ at $42^{\circ} \mathrm{C}$ followed by $30 \mathrm{~min}$ at $50^{\circ} \mathrm{C}$ and $10 \mathrm{~min}$ at $60^{\circ} \mathrm{C}[31,32]$. Amplification of the cDNA was then undertaken after adding $11 \mu \mathrm{l}$ of $2 \times \mathrm{KAPA}$ HiFi HotStart ReadyMix and $1 \mu \mathrm{l}$ of $2 \mu \mathrm{M}$ ISPCR primer [31, 32], followed by the cycle: $98^{\circ} \mathrm{C}$ for $3 \mathrm{~min}$, then 9 cycles of $98^{\circ} \mathrm{C}$ for $15 \mathrm{~s}, 67^{\circ} \mathrm{C}$ for $20 \mathrm{~s}, 72^{\circ} \mathrm{C}$ for $6 \mathrm{~min}$ and finally $72^{\circ} \mathrm{C}$ for 5 min. Finally, the cDNA was purified using a similar volume of AMPure beads (Beckman Coulter, Brea, California, USA) and eluted into $20 \mu \mathrm{l}$ of nuclease- free water (P1195; Promega). All libraries were prepared from 100 to 200 pg of cDNA using the Nextera XT Kit (Illumina, San Diego, California, USA), according to the manufacturer's instructions. The final cDNA libraries were purified using a 0.7:1 volumetric ratio of AMPure beads before pooling and sequencing on an Illumina Nextseq500 instrument in 75-base pair (bp) singleread high output mode at the Babraham Institute Sequencing Facility. A total of 5-10 million mappable reads per sample were obtained, with an average of 30-50 million reads per condition.

\section{Library mapping and trimming}

Trim Galore v0.4.2 was used with default parameters on raw Fastq sequence files. Mapping of the RNAseq data was done with Hisat v2.0.5 against the mouse GRCm38 genome, as guided by known splice sites taken from Ensemble v68.

\section{RNA-seq differential expression analysis}

Mapped RNA-seq reads were quantified and analysed using SeqMonk version v1.45.4 (http://www. bioinformatics.babraham.ac.uk/projects/seqmonk/). Differential expression analysis was performed using DESeq2 [33] implemented in SeqMonk setting a false discovery rate (FDR) $<0.05$.

\section{Statistical analysis}

Statistical analysis was performed using GraphPad Prism 7.0. The D'Agostino-Pearson omnibus normality test was performed followed by nonparametric Mann-Whitney test or multiple unpaired t-test with statistical significance determined using the Bonferroni- Sidak method, depending on the experiment. The data are shown as the mean \pm SD of three or more independent replicates. Significance was defined as values of $\mathrm{p}<0.05$. 


\section{Cellular Physiology Cell Physiol Biochem 2020;54:417-437

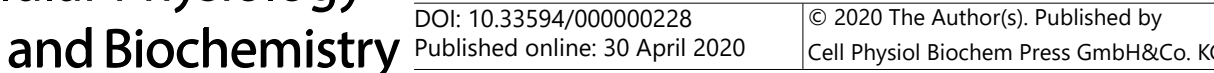 \\ Wołodko et al.: Obesity-Induced Leptin Resistance Results in Altered Transcription in \\ Cumulus Cells}

Statement of Ethics

All experiments were approved by Local Committee for the Ethical Treatment of Experimental Animals of Warmia- Mazury University (Agreement No. 80/2015, 15/2018, 38/2018), Olsztyn, Poland and were performed accordingly to the Guide for Care and Use of Laboratory Animals, endorsed by European legislation.

\section{Results}

Leptin signalling is impaired in the ovary of diet-induced obese mice

Initially we sought to characterise changes in leptin signalling in the ovary throughout DIO. Thus, mice were subjected to HFD for 4 and $16 \mathrm{wk}$ and whole ovaries and TC fraction were collected for mRNA or protein analysis (Fig. 1A). Oestrous stage was followed for twelve consecutive days, confirming that samples were collected in oestrus (Supplementary Fig. 1J, 1K) in cycling animals. Mice significantly gained BW and FM already at 4 wk, with an average absolute gain in BW of 13 grams (g) in the 16 wk HFD group (Supplementary Fig. $1 \mathrm{~A} ; \mathrm{p}<0.0001$ ). Three animals with comparable FI but BW gain less than $13 \mathrm{~g}$ were excluded from the statistical analysis and designated as HFD-low gainers (HFDLG). Also, after 4 and 16 wk HFD we confirmed high plasma levels of insulin (Supplementary Fig. $1 \mathrm{~F} ; \mathrm{p}<0.01, \mathrm{p}<0.001$ respectively) and leptin (Supplementary Fig. 1G; $<<0.01, \mathrm{p}<0.001$ respectively) and the establishment of impaired glucose tolerance and insulin resistance at 16 wk HFD (Supplementary Fig. 1H, 1I; p <0.01, p <0.001 respectively). Monitoring oestrous cycle revealed that the 4 wk HFD group had higher prevalence of oestrus counts compared with controls fed CD, whereas in the 16 wk HFD group there was a reduction in pro-oestrus (Supplementary Fig. 1J, $1 \mathrm{~K} ; \mathrm{p}<0.05, \mathrm{p}<0.01$ respectively).

Next, we isolated protein from whole ovaries and studied the abundance of components of the leptin signalling pathway. Whilst we found initial hyperactivation of leptin signalling pathway as demonstrated by upregulation of SOCS3 protein (Fig. 1B; Supplementary Fig. $3 \mathrm{~A} ; \mathrm{p}<0.05$ both) and a tendency to increased phosphorylation of STAT3 (Fig. 1C; $p=0.06$ ), after 16 wk HFD local leptin resistance was clearly established. This was evidenced by the decrease in abundance of leptin receptor (Fig. 1D; $<<0.01$ ), and a trend towards decreased phosphorylation of pTyr985 ObRb (Fig. 1E; $p=0.09$ ) and decreased phosphorylation of JAK2 (Fig. 1F; p <0.05), along with upregulation of SOCS3 (Fig. 1B; $<<0.001$, Supplementary Fig. $3 \mathrm{~A} ; \mathrm{p}<0.05$ ). In contrast, no differences were found in phosphorylation of other Tyr residues of ObRb (Supplementary Fig. 3B and 3C) or in PTP1B expression (Supplementary Fig. 3D). Additionally, there was reduced phosphorylation of STAT5 after 4 and 16 wk HFD (Fig. 1G; both $\mathrm{p}<0.01$ ).

Next, we sought to characterise the extent to which various ovarian components responded similarly to increased circulating leptin during obesity. We performed real-time PCR analysis of whole ovaries and TC fraction. Despite no significant changes after 4 wk HFD, the mRNA of Socs3 was increased after 16 wk HFD in both whole ovary (Fig. $1 \mathrm{H} ; \mathrm{p}<0.05$ ) and TC (Fig. 1H; p<0.001), in comparison to the CD group. Additionally, the mRNA level of Ptp1b was increased in both whole ovary and TC after 16 wk HFD (Fig. 1H; $<<0.01, \mathrm{p}<0.001$ respectively).

The aforementioned results suggested that SOCS3 could be an important player in the establishment of leptin resistance in the ovary of obese mice. Therefore, we examined SOCS3 localisation in ovaries of DIO and the genetically obese model: mice with a mutation in the obese gene $(\mathrm{ob} / \mathrm{ob})$. Immunohistochemistry (IHC) revealed the presence of SOCS3 protein in oocytes from follicles in all developmental stages (Fig. 1K-N; Supplementary Fig. $4 \mathrm{E}, 4 \mathrm{~F}, 4 \mathrm{I}, 4 \mathrm{~J}$ ); in addition, theca cells and GC from the respective follicles were stained, as well as the ovarian stroma (Fig. 1K-N). Importantly, we compared the IHC staining of SOCS3 and PTP1B in 16 wk HFD ovaries, which suggested that SOCS3 is the major ObRb inhibitor being expressed in the oocyte and GC, as PTP1B protein presented almost no staining in the oocyte (Supplementary Fig. 4G, 4H, 4K, 4L). As a control for the specificity of the IHC 


\section{Cellular Physiology and Biochemistry \\ Cell Physiol Biochem 2020;54:417-437

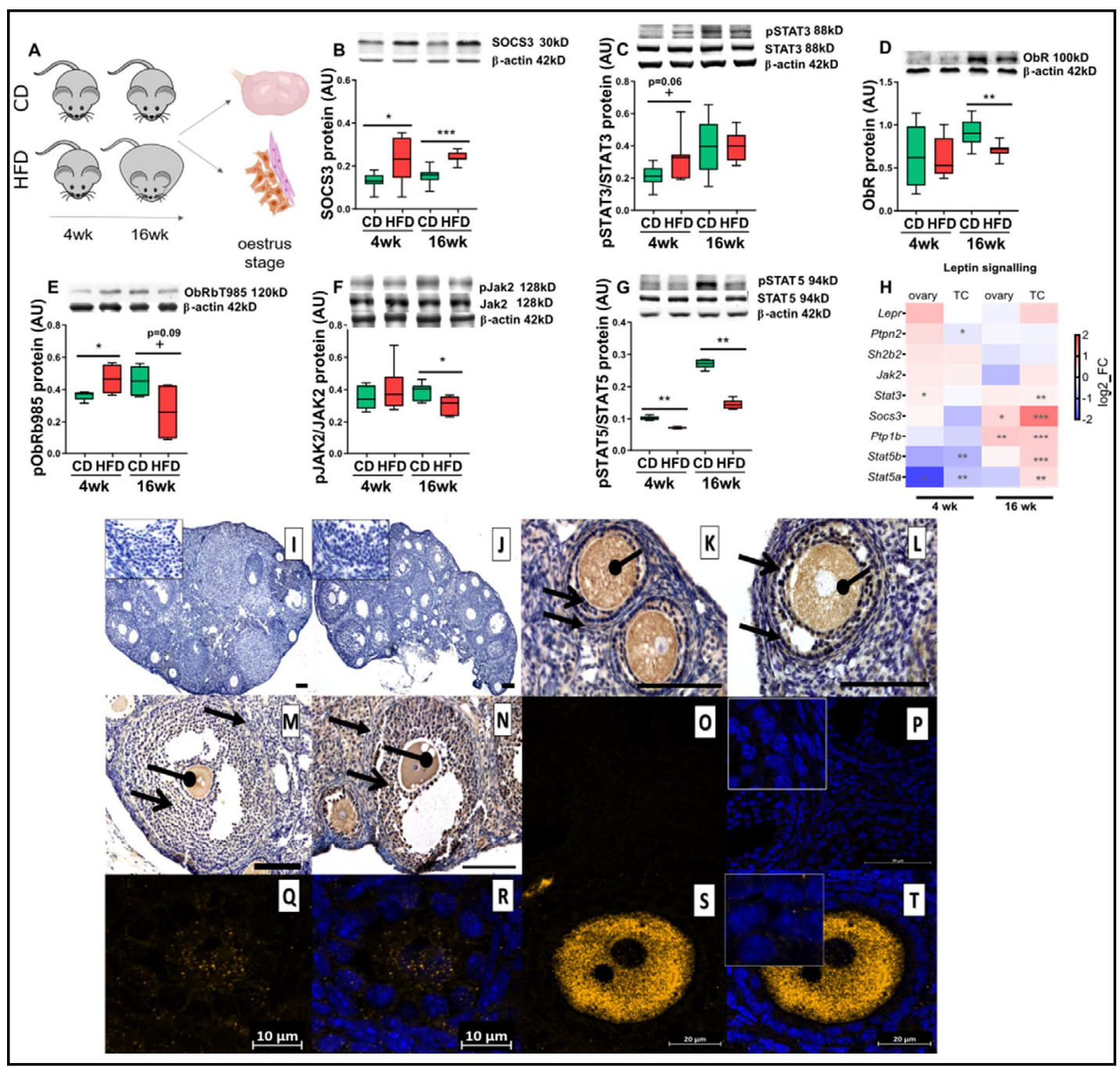

Fig. 1. The establishment of leptin resistance in the ovary of diet induced obese mice. (A) Experimental design: animals were maintained on chow diet (CD) or high fat diet (HFD) for 4 weeks (wk) or 16 wk. Protein abundance of components of the leptin signalling pathway in ovarian extracts analysed by Western blot or real-time PCR (RT-PCR). Abundance of (B) SOCS3 protein, (C) phosphorylation of STAT3, (D) leptin receptor (ObR), (E) phosphorylation of tyrosine 985 of leptin receptor, (F) phosphorylation of Janus kinase 2, (G) phosphorylation of STAT5. (H) Heatmap showing fold change in expression of mRNA of leptin signalling components measured in whole ovary or theca and stroma enriched (TC) fraction determined by RT-PCR. Immunohistochemical localisation of SOCS3 protein during follicle development in ovaries of mice subjected to diet-induced obesity ( $4 \mathrm{wk}$ and $16 \mathrm{wk}$ ). Positive staining in brown, counterstaining with heamatoxylin. Negative control stained with polyclonal rabbit IgG (I) $4 \mathrm{wk}$ CD and (J) $4 \mathrm{wk}$ HFD, localisation of SOCS3 in primary follicle (K) 4 wk CD and (L) 4 wk HFD, antral follicles (M) 16 wk CD and (N) 16 wk HFD. Staining is present in oocyte, granulosa and theca cells. Oval-headed arrow indicates oocyte; large-headed arrow indicates granulosa cells and small-headed arrow indicates theca cells. Scale bars represent $100 \mu \mathrm{m}$. The staining was confirmed by immunofluorescent localisation of SOCS3 (Q-T). Positive staining in orange, nuclear counterstaining with DAPI in blue. (O-P) negative control $16 \mathrm{wk}$ CD performed with polyclonal rabbit IgG, SOCS3 localised in (Q-R) primordial follicles $16 \mathrm{wk}$ CD, (S-T) primary follicles 16 wk CD. Images are representatives of 3 biological replicates. Inserts in left top corners are magnifications of granulosa cells. mRNA expression of Rpl37 and protein expression of $\beta$-actin were used to normalize the expression data. Each bar represents the mean \pm SD. Differences between groups were analysed by Mann-Whitney test. $\mathrm{N}=4-8$ for immunoblots and $\mathrm{N}=8$ for RT-PCR analysis. ${ }^{*} \mathrm{p}<0.05 ;{ }^{* *} \mathrm{p}<0.01 ;{ }^{* * *} \mathrm{p}<0.001 ;+\mathrm{p}=0.06$ or $\mathrm{p}=0.09$. 


\section{Cellular Physiology Cell Physiol Biochem 2020;54:417-437 \\ \begin{tabular}{ll|l} 
and Biochemistry & $\begin{array}{l}\text { DOl: 10.33594/000000228 } \\
\text { Published online: } 30 \text { April } 2020\end{array}$ & $\begin{array}{l}\text { O } 2020 \text { The Author(s). Published by } \\
\text { Cell Physiol Biochem Press GmbH\&Co. KG }\end{array}$ \\
\cline { 2 - 3 } &
\end{tabular} \\ Wołodko et al.: Obesity-Induced Leptin Resistance Results in Altered Transcription in \\ Cumulus Cells}

data, we used confocal microscopy for immunofluorescence detection of SOCS3 on sections from DIO and leptin-deficient $o b / o b(-/-)$ ovaries, confirming the localisation of SOCS3 (Fig. 1Q-T) and observing a weaker intensity of SOCS3 in both oocyte and GC in ovaries from $o b /$ $o b$ (Supplementary Fig. 4T, 4V) compared to wild type (+/+) (Supplementary Fig. 4S, 4U). These IF results confirmed the specificity of the staining, since SOCS3 is expected to be less abundant in tissues form the $o b / o b$ mouse [34]. Furthermore, we also inferred that impaired leptin signalling in the ovary is likely to have direct implications for the oocyte, since the gamete was shown to express SOCS3.

Cumulus cell transcriptome analysis: global transcriptome of CCs reflects body weight

Next, we repeated the protocol and subjected the animals to superovulation in order to collect CCs and analyse the transcriptome from $4 \mathrm{wk}$ and $16 \mathrm{wk}$ DIO protocols (Fig. 2A). A total of 50-80 CCs per animal were collected, from which RNA-seq libraries were generated using a Smart-seq2 oligo-dT method [31, 32], with separate RNA-seq libraries made from the CC from each female (see Supplementary Table 1). We then used Principal Component Analysis (PCA) to study the distribution of our samples according to global gene expression profile, and found that principal component 1 (PC1) was mainly driven by BW (Fig. 2B). Here we decided to include the HFDLG from the $16 \mathrm{wk}$ HFD group as a control, to test whether the transcriptional response could be linked to the BW of the animals; indeed, the HFDLG samples clustered together with $16 \mathrm{wk}$ CD of a similar weight (Fig. 2B). The correlation between PC1 and BW was $r=0.777$ ( $p=3.026 e-06)$ (Fig. 2C; Supplementary Table 2), which substantiates the physiological effect driven by BW, rather than the nature of the diet itself, on the global gene expression profile of CCs.

Next, we aimed to identify DEGs in CCs: for this analysis, we excluded the 3 HFDLG outliers from the $16 \mathrm{wk}$ HFD, so as to ensure a minimum of $13 \mathrm{~g}$ of BW difference between CD 16 wk and HFD $16 \mathrm{wk}$ and a BW difference of $5 \mathrm{~g}$ between CD 4 wk and HFD $4 \mathrm{wk}$ (Supplementary Fig. 1A). After DESeq2 analysis (FDR <0.05), a total of 997 DEGs in 4 wk HFD (373 upregulated and 624 downregulated; Fig. 2D; Supplementary Table 3) and 846 DEGs in 16 wk HFD (203 upregulated and 643 downregulated; Fig. 2E; Supplementary Table 3) were identified. Surprisingly, amongst the DEGs only 52 genes were common between the 4 wk and 16 wk comparisons (Fig. 2F), highlighting the differences in pathophysiology of early and late stages of obesity. Gene ontology (GO) $[35,36]$ analysis of the DEG lists showed that transcripts with increased abundance in 4 wk HFD were primarily linked to nitrogen and lipid metabolism and transport, but also cell stress and reactive oxygen species generation (Supplementary Table 4). Transcripts downregulated after 4 wk HFD were mapped to pathways involved in regulation of macromolecule biosynthesis and gene expression, as well as chromatin organisation/histone modification and regulation of cell cycle (Supplementary Fig. 5A; Supplementary Table 4). After 16 wk HFD treatment, upregulated genes were associated with negative regulation of development and cellular component organisation, while pathways highlighted for downregulated genes included localisation, transport and positive regulation of metabolism (Supplementary Fig. 5B; Supplementary Table 5). Therefore, in this analysis we identified the gene signatures in CCs altered at the onset and later development of DIO.

Finally, we wished to examine the impact of BW as a factor on gene expression in CCs. Therefore, we examined the expression of the 846 DEGs identified in 16 wk HFD group in the 16 wk HFDLG and CD samples. Strikingly, for this set of genes, the HFDLGs presented an expression pattern closer to $16 \mathrm{wk}$ CD than to 16 wk HFD (Fig. 2G), revealing a very strong correlation between BW and global gene expression profile in CCs indicative of the impact of female physiology on CCs gene expression. As CCs represent an important accessible source of biomarkers for the assessment of reproductive potential of the mother, they are often sampled in assisted reproductive technologies (ART) to profile biomarkers of oocyte competence or embryo quality. Thus, we looked for known markers of embryo quality [25] in 
Cumulus Cells

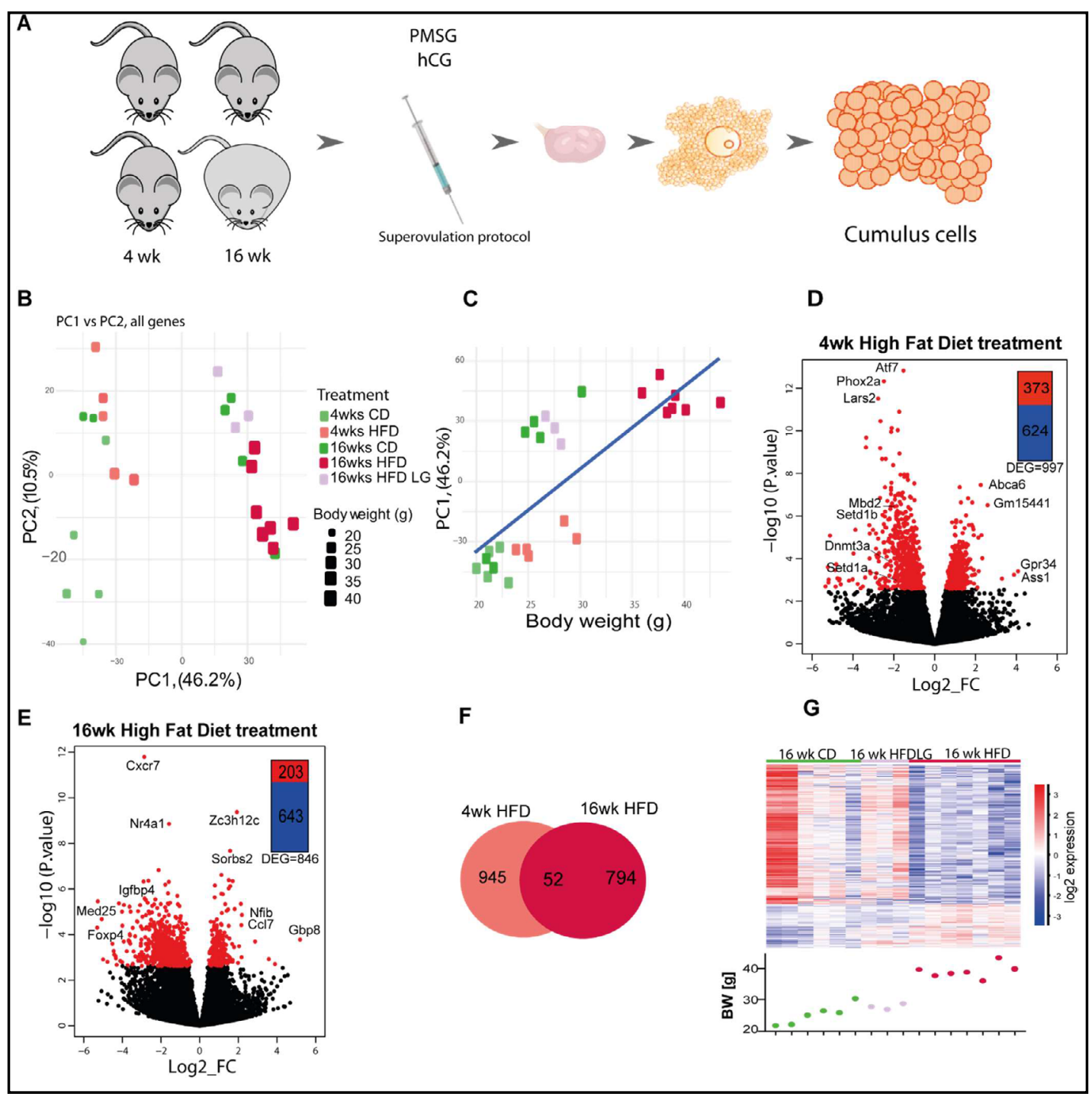

Fig. 2. Cumulus cell transcriptome analysis in diet induced-obese mice reveals strong correlation with body weight. (A) Experimental design: mice were subjected to the indicated dietary protocol, superovulated and cumulus cells were collected from cumulus-oophorus-complexes. RNA-seq analysis of gene expression in cumulus cells obtained from mice after 4 or 16 weeks (wk) on chow diet (CD), high fat diet (HFD) or low gainers on HFD (HFDLG). N= 3-7 mice per group. (B) Principal component analysis of global transcriptome shows samples cluster into 2 groups accordingly to their body weight (BW). (C) Correlation of Principal Component 1 (PC1) with BW; r=0.777, p=3.026e-06. Volcano plots showing distribution of differentially expressed genes in (D) $4 \mathrm{wk}$ HFD and (E) $16 \mathrm{wk}$ HFD; genes with false discovery rate (FDR) $<0.05$ colored red. (F) Venn diagram showing the number of genes differentially expressed at false discovery rate $<0.05$ between $4 \mathrm{wk}$ and $16 \mathrm{wk}$ groups. (G) Heatmap of 846 DEGs identified by DESeq2 analysis between 16 wk CD and HFD CCs, including data for HFDLG CC samples, with BW of mice at time of collection plotted below. Heatmap representing fold of change of gene expression. log2_FC of reads per million (RPM).

the 16 wk DEGs and discovered that Nfib was upregulated and Ptgs2 and Trim28 transcripts were downregulated in CCs (Supplementary Fig. 6A-C). The altered expression of these markers in CCs during late obesity might indicate direct consequences for oocyte and embryo quality, as previously proposed [24, 37-39]. 


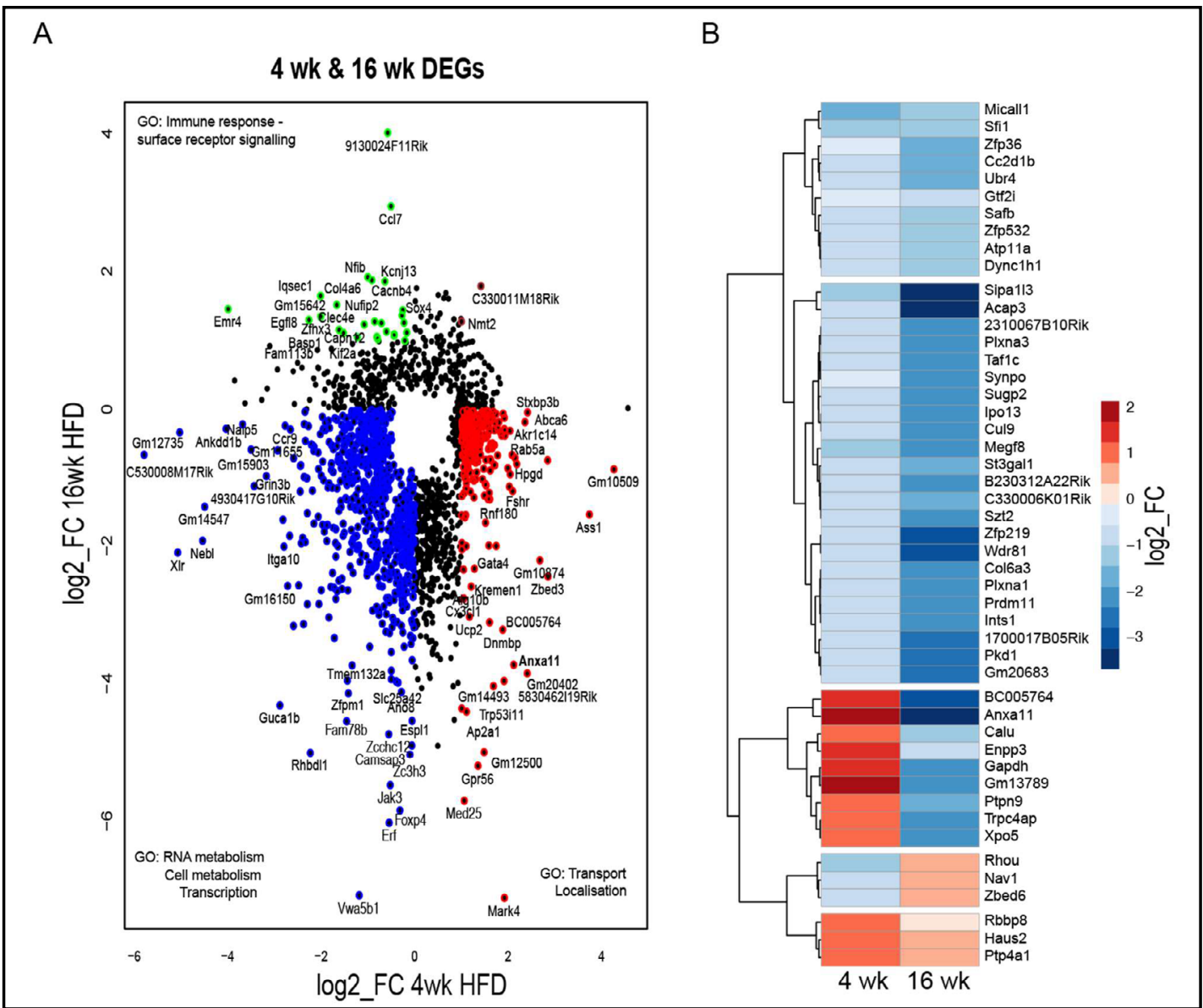

Fig. 3. Temporal changes in the transcriptome of cumulus cells during obesity progression. DESeq2 analysis of transcriptome data in cumulus cells (CC) of mice fed high fat diet (HFD) for 4 or 16 weeks (wk). N= 3-7 mice per group. (A) Scatter plot presents genes differentially expressed in at least one condition (false discovery rate $<0.05$ ) in CC after 4 wk (997 genes) or 16 wk HFD (846 genes). Genes coloured blue are downregulated after both $4 \mathrm{wk}$ and $16 \mathrm{wk}$ HFD; green downregulated after 4 wk HFD and upregulated after 16 wk HFD; brown upregulated after both 4 wk HFD and after 16 wk; red upregulated after 4 wk HFD and downregulated after 16 wk HFD. (B) Heatmap presents hierarchical clustering of genes significantly changed in both 4 and 16 wk HFD normalised by average control fed chow diet. Genes cluster in group downregulated after $4 \mathrm{wk}$ and $16 \mathrm{wk}$ HFD, group upregulated after $4 \mathrm{wk}$ and downregulated after 16 wk HFD, group downregulated after $4 \mathrm{wk}$ and upregulated after $16 \mathrm{wk}$ HFD and group upregulated after both 4 wk and 16 wk HFD. Gene ontology analysis performed with Gene Ontology Enrichment Analysis and Visualisation Tool. log2_FC of reads per million (RPM).

\section{Differential effects on gene expression in CCs early and late in obesity}

We next sought to characterise how gene expression in CCs changes between the early and late stages of DIO. To do this, we evaluated the expression of the 997 DEGs from $4 \mathrm{wk}$ and the 846 DEGs from 16 wk HFD at both time-points (Fig. 3A). Note that in this analysis, not all the DEGs attain a significant difference at both time points (as noted above in Fig. 2F), but we are aiming to identify the directionality of their expression changes throughout obesity. Only 3 DEGs were upregulated in both conditions (Fig. 3A), whereas we found 252 genes upregulated in 4 wk HFD but downregulated in 16 wk HFD, mainly linked to cell transport and localisation. Conversely, the 30 genes downregulated in $4 \mathrm{wk}$ HFD, but upregulated in 16 wk HFD referred to immune response (Fig. 3A). Finally, a sum of 694 DEGs were downregulated in both 4 and 16 wk HFD, mainly involved in metabolism and transcription (Fig. 3A; Supplementary Table 6). This analysis revealed a large subset 


\section{Cellular Physiology Cell Physiol Biochem 2020;54:417-437 \\ \begin{tabular}{ll|l} 
and Biochemistry & $\begin{array}{l}\text { DOl: 10.33594/000000228 } \\
\text { Published online: } 30 \text { April } 2020\end{array}$ & $\begin{array}{l}\text { O } 2020 \text { The Author(s). Published by } \\
\text { Cell Physiol Biochem Press GmbH\&Co. KG }\end{array}$ \\
\cline { 1 - 3 } &
\end{tabular} \\ Wołodko et al.: Obesity-Induced Leptin Resistance Results in Altered Transcription in \\ Cumulus Cells}

of genes being downregulated throughout obesity, but also genes with opposite profile which suggests an adaptive response of CCs to changes in the physiology of the mother. In a parallel approach, we intersected the DEGs datasets from 4 wk HFD and 16 wk HFD and from the 52 DEGs in common between the two timepoints (Fig. 2F) identified 5 main clusters of DEGs. The first 2 clusters comprised 33 genes downregulated in both $4 \mathrm{wk}$ and $16 \mathrm{wk}$ HFD (Supplementary Table 6), with the most significantly deregulated gene at 4 wk HFD MICAL Like (Micall) 1 (FDR = 0.0002), but other genes like Dynein cytoplasmic 1 heavy chain (Dync1h) or Collagen (Col) $6 a 3$ (Fig. 3B; Supplementary Table 6) were also found. Clusters 3 and 4 revealed the most interesting set of genes concerning disease progression, due to their opposite profile between $4 \mathrm{wk}$ and $16 \mathrm{wk}$ treatment. In cluster 3 we found genes like Annexin (Anxa) 11 or Exportin (Xpo) 5 strongly upregulated in 4 wk HFD, but inhibited in 16 wk HFD (Fig. 3B), whereas in cluster 4 we found genes like Ras homology family member $U$ (Rhou) with opposing profiles at the two time points (Fig. 3B). Finally, cluster 5 comprised the 3 genes significantly upregulated throughout obesity (Fig. 3B). Therefore, in this analysis we identified gene expression profiles in CCs that represent a valuable tool to assess disease progression in the ovary of obese mice.

The contribution of leptin to changes in gene expression in CCs from obese mice

After identifying the major molecular changes in leptin signalling in the ovaries of DIO females, we aimed to establish an in vivo system that would expose the ovaries to the elevated levels of circulating leptin, a feature seen in obesity [7], but lacking all remaining traits of obesity. Thus, we conceived a model for pharmacological hyperleptinemia. Sixteen days of leptin treatment resulted in a consistent drop in BW and FM (Supplementary Fig. 2B, $2 \mathrm{E} ; \mathrm{p}<0.01$ ) and increased incidence of oestrus (Supplementary Fig. 2G; $<<0.05$ ). The ovaries from animals in oestrus stage were collected for mRNA and protein analysis. Whereas injections of $100 \mu \mathrm{g}$ leptin for 9 days did not change the protein expression of leptin signalling molecules (Supplementary Fig. 7A-J), ObR expression and phosphorylation of Tyr985 and STAT5 were decreased after $16 \mathrm{~d}$ (Supplementary Fig. 7A, 7B, 7G; $<<0.05, p=0.09, p<0.01$ respectively), together with increased SOCS3 (Supplementary Fig. 7I, 7J; $p<0.01, p<0.05$ respectively). Validation of a pharmacological hyperleptinemia model allowed us to access ovarian samples from mice with hyperactivation of ObRb, here indicated by increased SOCS3 expression, but lacking the remaining traits of obesity.

Next, we collected CCs from superovulated mice after LEPT treatment and analysed their transcriptome (Fig. 4A). After DESeq2 analysis (FDR <0.05), a total of 2026 differently expressed genes were found between LEPT and CONT samples (1212 genes upregulated and 814 downregulated) (Fig. 4B). Gene ontology analysis of the DEG lists showed that the upregulated genes for LEPT were associated primarily with cellular organisation, the cytoskeleton and immune responses, supporting the immune-mediating role of leptin as evidenced before [40-42]. Conversely, amongst the LEPT downregulated pathways were cell metabolism as well as chromatin organisation and histone modifications (Supplementary Fig. 8; Supplementary Table 7). Next, based on the hypothesis that early-onset obesity is followed by hyperactivation of leptin signalling in the ovary, we overlapped both 4 wk DIO model and LEPT transcriptome datasets, aiming to pinpoint the LEPT driven effects in the CC transcriptome during early obesity. PCA revealed the clustering of $4 \mathrm{wk}$ DIO and CONT samples, and LEPT samples apart (Fig. 4C). Indeed, leptin treatment seemed to drive PC1. Next, we overlapped the DEGs from 4 wk HFD and LEPT protocols and found 144 genes upregulated in both LEPT and 4 wk HFD. These were related to response to toxins, transport and glucose metabolism (Fig. 4D; Supplementary Table 8). More specifically, the genes Lipocalin (LCn) 2, Anxa11 and Glucose-6-phosphate dehydrogenase x-linked (G6pdx) were amongst the most significant (Fig. 4D). Conversely, the GO terms associated with the 177 downregulated genes in both protocols were metabolism and gene expression regulation (Fig. 4D; Supplementary Table 8). A number of downregulated genes were found to encode important epigenetic factors, such as Dna segment, chr 14, abbott 1 expressed o (Tasor), Lysine (k)-specific methyltransferase $2 d$ (Kmt2d/Mll2), Methyl-cpg binding domain protein (Mbd) 2, 


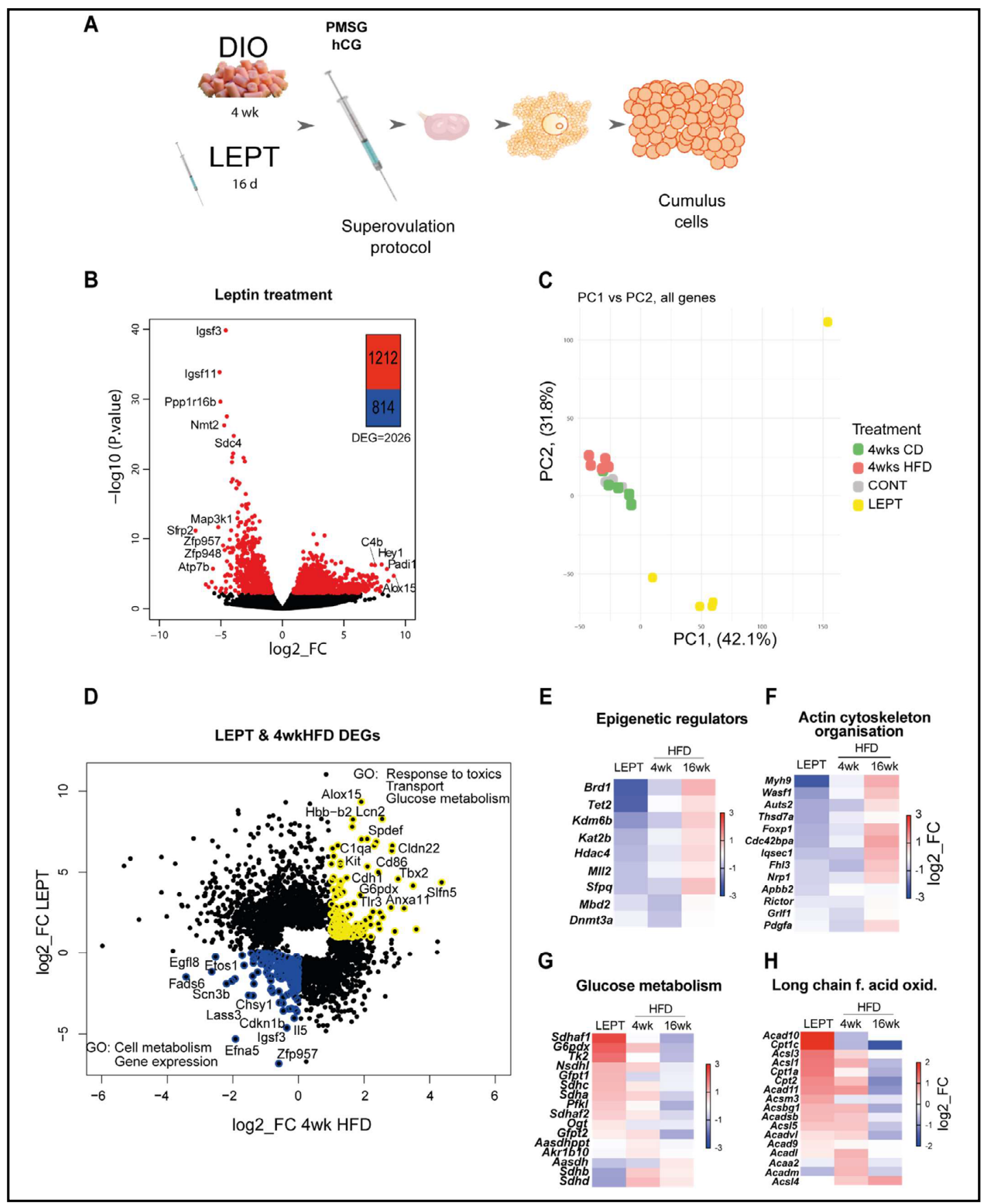

Fig. 4. Pharmacologically hyperleptinemic mouse model shows leptin effects in the transcriptome of cumulus cells during early obesity. (A) Experimental design: mice were fed chow diet (CD) of high fat diet (HFD) for 4 weeks (wk) (4 wk DIO) or injected with saline (CONT) or $100 \mu \mathrm{g}$ of leptin (LEPT) for 16 days, followed by superovulation and collection of cumulus cells from cumulus-oophorus-complexes. RNA-seq analysis of gene expression in cumulus cells. $\mathrm{N}=3-7$ mice per group. (B) Volcano plots showing distribution of differentially expressed genes in LEPT group; genes with False Discovery Rate $<0.05$ coloured red. (C) Principal component analysis of global transcriptome shows LEPT effect is the main source of variance in the data (first principal component, PC1). DESeq2 analysis of transcriptome data in cumulus cells. (D) Scatter plot presents genes differentially expressed in cumulus cells in LEPT or in 4 wk HFD, with False Discovery Rate $<0.05$. Those coloured blue are down-regulated both in response to leptin treatment and 4 wk HFD; those in yellow upregulated by both treatments. Heatmaps presenting fold of change in expression of genes associated with the following pathways: (E) epigenetic regulation; (F) actin cytoskeleton organisation; (G) glucose metabolism; (H) long chain fatty acid oxidation in CC. Gene ontology analysis performed with Gene Ontology Enrichment Analysis and Visualisation Tool. log2_FC of reads per million (RPM). 


\section{Cellular Physiology Cell Physiol Biochem 2020;54:417-437 \\ \begin{tabular}{ll|l} 
and Bl: 10.33594/000000228 & $\begin{array}{l}\text { O } 2020 \text { The Author(s). Published by } \\
\text { Cell Physiol Biochem Press GmbH\&Co. KG }\end{array}$ \\
\cline { 2 - 3 } & Published online: 30 April 2020 &
\end{tabular} \\ Wołodko et al.: Obesity-Induced Leptin Resistance Results in Altered Transcription in \\ Cumulus Cells}

and DNA methyltransferase (Dnmt) $3 a$ (Fig. 4E), which suggested epigenetic dysregulation. Another important effect that could be attributed to leptin in early stages of obesity was the repression of genes mediating actin-cytoskeleton reorganisation (Fig. 4F; Supplementary Table 7). Furthermore, we assessed the potential impact of leptin on genes involved in CC metabolism, and verified the role of leptin on glucose metabolism (Fig. 4G) and fatty acid oxidation (Fig. 4H), which was reflected in the similarities between LEPT and 4 wk HFD. Here, we questioned how lack of leptin signalling could be detrimental metabolically. For instance, the oocyte is unable to metabolise glucose due to low phosphofructokinase activity [43], highlighting the importance of glycolytic activity of CCs in the generation of pyruvate [44]. This function appeared to be decreased in 16 wk HFD, which could be the result of the establishment of leptin resistance in the ovary. As a consequence, the transport of pyruvate into the oocyte would be decreased, which could directly impact the tricarboxylic acid cycle (TCA) and adenosine triphosphate (ATP) generation (Supplementary Fig. 9B) [45]. Leptin is also known to be key for free fatty acid (FFA) metabolism, promoting their oxidation and regulating the homeostasis of triglycerides in a cell $[46,47]$. Thus, disruption of leptin signalling in 16 wk HFD CCs (Supplementary Fig. 9A) could be relevant for lipotoxicity and stress previously described in obese ovaries [48] (Supplementary Fig. 9E, 9F). In general, hyperactivation of leptin signalling in CCs seemed to be linked primarily to impaired cell membrane transport and endocytosis, but also cell metabolism and gene expression regulation.

\section{Discussion}

The present study characterises the molecular mechanisms underlying the establishment of leptin resistance in the ovary of DIO mice. Furthermore, making use of sensitive methods for reduced-cell number RNA-seq, we studied the transcriptome of the somatic cells surrounding the oocyte from mice subjected to DIO for $4 \mathrm{wk}$ and $16 \mathrm{wk}$, as well as validated model for pharmacological hyperleptinemia - a system presenting exclusively increased circulating levels of leptin amongst all features of obesity, which allowed us to pinpoint the exclusive effects of leptin-SOCS3 ovarian hyperactivation during early-onset of obesity.

Leptin is a major adipokine, which was initially linked to satiety [6]. The establishment of leptin resistance at different levels in the body has been documented in recent years as one of the outcomes of obesity. Accordingly, leptin signalling is deregulated in the hypothalamus [49] and liver of obese human and mice [50]. However, the same was not found in kidney [51] or heart [52] of obese humans, suggesting an organ-specific response. We confirmed here, for the first time, the establishment of leptin resistance in the ovary of obese female mice. This poses very important questions on the long-term effects of obesity on ovarian performance, concerning the known local roles of leptin on follicular growth [12], ovulation [13], and oocyte quality [53]. Leptin action in the ovary is highly intricate and its effects bimodal. Low leptin levels in circulation facilitate the transition from primary to secondary follicles [12], but leptin is also required for ovulation, possibly supporting CC expansion through cyclooxygenase (COX) 2 and hyaluronic acid synthase (HAS) 2 activity [13]. Indeed, $o b / o b$ mice contain antral follicles in their ovaries (data not shown), but fail to ovulate. Thus, during obesity progression, altered leptin signalling in the ovary could lead to functional failure and infertility through different mechanisms, mainly characterised by the hyperactivation of $\mathrm{ObRb}$ in the onset of obesity and complete failure in signalling in late obesity.

Our first aim was to elucidate the molecular mechanisms leading to the establishment of leptin resistance in the obese ovary. The analysis of different $\mathrm{ObRb}$ Tyr domains highlighted the decrease in pTyr985 along with pJAK2 in ovaries from 16 wk HFD mice, concomitant with the increase in SOCS3 protein and decrease in pSTAT5. Functionally, STAT5 phosphorylation in the mouse ovary was shown to be crucial for prolactin signalling and cell proliferation during follicular growth [54], as well as corpus luteum formation [55]. Hence, reduced 


\section{Cellular Physiology Cell Physiol Biochem 2020;54:417-437 \\ \begin{tabular}{ll|l} 
and Biochemistry & $\begin{array}{l}\text { DOl: 10.33594/000000228 } \\
\text { Published online: } 30 \text { April } 2020\end{array}$ & $\begin{array}{l}\odot 2020 \text { The Author(s). Published by } \\
\text { Cell Physiol Biochem Press GmbH\&Co. KG }\end{array}$ \\
\cline { 2 - 3 }
\end{tabular} \\ Wołodko et al.: Obesity-Induced Leptin Resistance Results in Altered Transcription in \\ Cumulus Cells}

pSTAT5 signalling per se could compromise oocyte maturation and fertility during obesity. Importantly, we observed that SOCS3 staining in the oocyte occurred mainly in response to $\mathrm{ObRb}$ activation, since the $o b / o b$ mouse presented weaker staining. This suggests a direct impact of disrupted ovarian leptin signalling on oocyte quality through SOCS3 activation. Indeed, at 16 wk DIO, we observed different levels of Socs 3 transcribed in various ovarian components. Our RNA-seq data revealed that Socs 3 was increased at 4 wk HFD, but decreased at 16 wk HFD in CCs, whereas in the TC fraction it was upregulated at both time points. This may suggest blunted ObRb signalling in CCs at 16 wk HFD, once the transcription of the major components of the pathway was inhibited (Supplementary Fig. 9A). Therefore, leptin signalling in CCs seems to be highly sensitive to obesity and maternal metabolic performance.

Having an understanding of the impact of obesity on leptin signalling in the ovary, we then analysed the transcriptome of CCs from DIO mice. A major observation of this study was the striking correlation between BW and the global gene expression profile of CCs. On the other hand, other studies showed functional changes in the ovary, including depletion of primordial follicles and inflammation in HFD mice, irrespective of gain in BW [56]. Differences in diet composition, as well as variable length of exposure to diet, might account for the differences between studies. Also the aforementioned study did not present a global gene expression analysis. Interestingly, when found that the expression profile of HFD-DEGs in the HFDLG CCs was similar to that in $16 \mathrm{wk} C D$, clearly demonstrating the impact of maternal BW, which probably largely reflects adiposity in this model, on gene expression in CCs.

Another major outcome of the transcriptome analysis of CCs was the identification of gene signatures altered in early vs late stages of obesity. After 4 wk HFD, mainly genes involved in glucose metabolism and cell membrane trafficking were differently expressed. The use of the pharmacologically hyperleptinemic model allowed us to dissect the contribution of hyperactivation of ObRb to the major changes taking place in CCs in early obesity. Increased activation of the JAK-STAT cascade seemed mainly to impair cellular trafficking and paracrine transfer of macromolecules. This is known to be a crucial process for the metabolic cooperation between the oocyte and somatic cells [23]. Cell trafficking and nutrient mobilisation to the oocyte, as well as the uptake of signalling molecules from the oocyte, is fundamental for COCs expansion and oocyte maturation [23]. Indeed, the genes Micall1 and Unc-51 Like Kinase (Ulk) 4 are important mediators of endocytosis [57, 58], and were shown to be regulated by Stat3. Furthermore, amongst the genes upregulated in both 4 wk HFD and LEPT we found Lcn2, associated with lipid and hormone transport [59], Claudine (Cldn) 22, a component of tight junctions [60], and Anxa11, known to be involved in transmembrane secretion [61]. This is suggestive of the effects of leptin in altering transmembrane transport in the early-onset of obesity.

We also identified the metabolic gene Arachidonate 15-Lipoxygenase (Alox15), and the transcription factor Hes Related Family BHLH Transcription Factor With YRPW Motif (Hey) 1, were amongst the most significantly upregulated genes in both 4 wk HFD and LEPT (Supplementary Table 8). The transcriptional repressor HEY1 is directly activated by Notch Receptor (NOTCH) 2 during follicular development, and both HEY1 and NOTCH2 were shown to be increased in proliferating granulosa cells and can contribute to ovarian overstimulation and premature follicular failure [62]. These effects further demonstrate the detrimental role of increased $\mathrm{ObRb}$ activation during the onset of obesity in cell trafficking and immune response.

Amongst the downregulated signatures in both 4 wk HFD and LEPT we found genes that encoded for important epigenetic factors, such as Tasor, Kmt2d/Mll2, Mbd2, and Dnmt3a (Fig. 4D, Supplementary Table 8), which could indicate epigenetic dysregulation in these cells in early obesity being mediated by leptin. Another striking result was the coordinate downregulation of genes involved in cytoskeleton and actin-filament organisation again in $4 \mathrm{wk}$ HFD and LEPT. As in axons, microtubules form the cytoskeletal core of granulosa cell transzonal projections (TZPs), which provide tracks for the polarized translocation of secretory pathway organelles [63]. Thus, by impairing the intrinsic stability of TZPs in granulosa cells, leptin could be affecting the paracrine exchanges between oocytes and 


\section{Cellular Physiology Cell Physiol Biochem 2020;54:417-437 \\ \begin{tabular}{ll|l} 
and Biochemistry $\begin{array}{l}\text { DOl: 10.33594/000000228 } \\
\text { Published online: } 30 \text { April 2020 }\end{array}$ & $\begin{array}{l}\text { O } 2020 \text { The Author(s). Published by } \\
\text { Cell Physiol Biochem Press GmbH\&Co. KG }\end{array}$ \\
\cline { 2 - 3 } &
\end{tabular} \\ Wołodko et al.: Obesity-Induced Leptin Resistance Results in Altered Transcription in \\ Cumulus Cells}

somatic cells, an instrumental system for oocyte maturation [64]. Indeed, the oocyte is in extreme need of the metabolites generated in CCs, but also signalling factors such as growth differentiation factor (GDF) 9 secreted by the oocyte and required to orchestrate CCs function. Leptin seemed to support the TCA cycle at 4 wk HFD (Supplementary Fig. 9B), which suggested to us that at this early stage the boost in leptin signalling in CCs could actually have beneficial effects, following the positive response on oocyte competence and GDF9 signalling (Supplementary Fig. 9D). However, at 16 wk HFD the inferred drop in CC metabolic fitness was paralleled by a decrease in the main paracrine mediators of oocyte maturation and responsiveness to GDF9 (Supplementary Fig. 9B-D), which invariably suggest compromised oocyte quality. The aforementioned events are an important part of COC expansion, a complex mechanism triggered by luteinizing hormone (LH), in which bidirectional exchange of metabolites and signalling factors between the oocyte and CCs leads to maturation of the gamete and resumption of meiosis [22]. This process is tightly regulated by immune mediators, particularly interleukin (IL) 6 [65]. Indeed, as well as being highlighted in our transcriptome analysis, the role of leptin in the inflammatory response, in particular mediating innate immunity through IL6, has been described before [55]. Consequently, the detrimental effect of obesity could be related to increased leptin signalling at 4 wk HFD, but most likely through its failure at 16 wk HFD (Supplementary Fig. 9A). Generally, in the early stages of obesity, leptin downregulated potentially important epigenetic mediators and genes involved in cytoskeletal organisation in CCs.

The analysis of 16 wk HFD DEGs, as well as the profile of temporal changes revealed genes involved in cell trafficking as Micall1 or Dync1h, involved in protein transport, positioning of cell compartments, and movement of structures within the cell [66] to be decreased in $4 \mathrm{wk}$ and 16 wk HFD. Furthermore, the most increased gene in 16 wk HFD was the Guanylatebinding protein (Gbp) 8 (Supplementary Table 5), a component of cellular response to interferon-gamma [67]. Another gene upregulated at 16 wk HFD was Rhou, a gene that regulates cell morphology [68]. Considering also the high expression level of inflammatory mediators at this stage, the activated pathways may well be an outcome of lipotoxicity previously described in the obese ovary [48]. Thus, during obesity ovarian cells are trying to accommodate the surplus of lipid compounds, which is likely to activate mechanisms of cellular reorganisation. Overall, early changes in CC transport, gene expression and epigenetic regulation are followed by mounting inflammatory pathways and cellular rearrangement to accommodate the lipid surplus. Functional studies in CCs with variable levels of leptin and $\mathrm{ObRb}$ activity are needed to confirm the present observations.

Fig.5. Graphical representation of the main temporal changes in the ovary of obese mice. During early obesity (4 weeks of diet-induced obesity, DIO) increased leptin signalling affects the transcriptome of cumulus cells (CCs). RNAseq analysis revealed mainly alterations in genes involved in membrane trafficking, cytoskeleton organisation and glucose metabolism. During late obesity (16 wk DIO) leptin resistance is established,

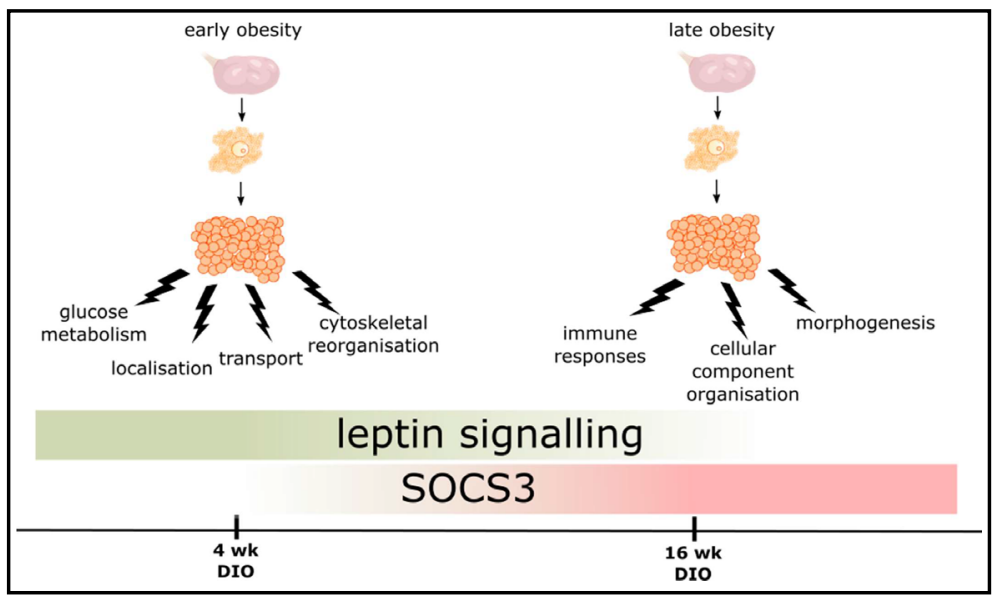
which causes accumulation of SOCS3 in the ovary. Transcriptome analysis of CCs at this timepoint indicated the activation of the inflammatory response and cellular anatomical morphogenesis, with inhibition of metabolism and transport. 


\section{Cellular Physiology Cell Physiol Biochem 2020;54:417-437

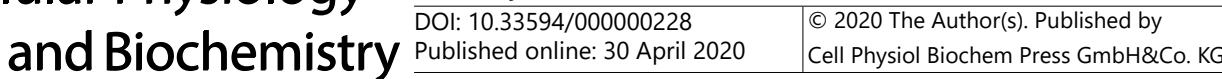 \\ Wołodko et al.: Obesity-Induced Leptin Resistance Results in Altered Transcription in Cumulus Cells}

\section{Conclusion}

In conclusion, we found that the ovaries of obese mice develop leptin resistance and that global gene expression in CCs was strikingly correlated with BW. Mechanistically, failure in ovarian leptin signalling was mediated by SOCS3 overexpression, and inhibition of pTyr985 and pJAK2. Initially, during the onset of obesity the hyperactivation of leptin signalling was linked to increased expression of genes for cell trafficking and cytoskeleton organisation, and inhibition of genes associated with epigenetic regulations in CCs. Conversely, in late obesity, altered gene signatures were mainly linked to inflammatory response and morphological rearrangement (Fig. 5). This analysis revealed for the first time the temporal changes in gene expression in CCs during obesity progression. The present study opens new avenues to better understand the impact of altered leptin signalling in obese ovary in both oocyte and granulosa cells function throughout its development, and potential implications for early embryo development.

\section{Acknowledgements}

We would like to thank Dr Leslie Paul Kozak and Dr Magdalena Jura for their support with the validation and characterisation of the mouse obese phenotype; Dr Jorg Morf for the constructive discussion and suggestions on the analysis of the transcriptome data; Dr Daniel Murta for providing the of mouse ovarian slides; and Dr Fatima Santos and Dr Krzysztof Witek for their support with the imaging and confocal microscopy.

\section{Statement of Ethics}

Animal experiments conform to internationally accepted standards and have been approved by the appropriate institutional review body.

\section{Funding Sources}

Work was supported by grants from the Polish National Science Centre (No. 2014/15/D/ NZ4/01152 and 2016/23/B/NZ4/03737) awarded to A. G. and the UK Biotechnology and Biological Sciences Research Council and Medical Research Council (BBS/E/B/000C0423, MR/K011332/1, MR/S000437/1) awarded to G.K.; A. G. was supported by Horizon 2020 Marie Curie Individual Fellowship (MOBER) and by the KNOW Consortium: "Healthy Animal - Safe Food” (Ministry of Sciences and Higher Education; Dec: 05-1/KNOW2/2015).

\section{Authors Contribution}

KW data acquisition, analysis and interpretation of the data, writing the manuscript; EW data acquisition, analysis and interpretation of the data; MA, data acquisition and analysis; JCF bioinformatic analysis and interpretation of data, revising the manuscript; GK supervision, funding, revising the manuscript; AG conception and design, funding acquisition, acquisition of data, bioinformatic analysis and interpretation of data, writing and revising of the manuscript.

\section{Disclosure Statement}

The authors have no conflict of interest to declare. 


\section{Cellular Physiology Cell Physiol Biochem 2020;54:417-437 \begin{tabular}{l|l} 
DOI: 10.33594/000000228 & (c)20 The Author(s). Published by
\end{tabular} and BiOChemistry Published online: 30 April $2020 \quad$ Cell Physiol Biochem Press GmbH\&Co. KG \\ Wołodko et al.: Obesity-Induced Leptin Resistance Results in Altered Transcription in Cumulus Cells}

\section{References}

1 Schelbert KB: Comorbidities of Obesity. Prim Care Clin Off Pract 2009;36:271-285.

2 Pasquali R, Patton L, Gambineri A: Obesity and infertility. Curr Opin Endocrinol Diabetes Obes 2007;14:482-487.

3 Dağ ZÖ, Dilbaz B: Impact of obesity on infertility in women. J Turkish Ger Gynecol Assoc 2015;16:111-117.

4 Unger RH, Zhou YT: Lipotoxicity of beta-cells in obesity and in other causes of fatty acid spillover. Diabetes 2001;50:S118-121.

5 Robker RL, Wu LLY, Yang X: Inflammatory pathways linking obesity and ovarian dysfunction. J Reprod Immunol 2011;88:142-148.

6 Friedman JM, Halaas JL: Leptin and the regulation of body weight in mammals. Nature 1998;395:763-770.

7 Maffei M, Halaas J, Ravussin E, Pratley RE, Lee GH, Zhang Y, Fei H, Kim S, Lallone R, Ranganathan S, Kern PA, Friedman JM: Leptin levels in human and rodent: Measurement of plasma leptin and ob RNA in obese and weight-reduced subjects. Nat Med 1995;1:1155-1161.

8 Vaisse C, Halaas JL, Horvath CM, Darnell JE, Stoffel M, Friedman JM: Leptin activation of Stat3 in the hypothalamus of wild-type and ob/ob mice but not db/db mice. Nat Genet 1996;14:95-97.

9 Cava A La, Matarese G: The weight of leptin in immunity. Nat Rev Immunol 2004;4:371-379.

10 Sierra-Honigmann MR, Nath AK, Murakami C, Garcia-Cardena G, Papapetropoulos A, Sessa WC, Madge LA, Schechner JS, Schwabb MB, Polverini JP, Flores- Riveros JR: Biological action of leptin as an angiogenic factor 1. Science 1998;281:1683-1686.

11 Quennell JH, Mulligan AC, Tups A, Liu X, Phipps SJ, Kemp CJ, Herbison AE, Grattan DR, Anderson GM: Leptin Indirectly Regulates Gonadotropin-Releasing Hormone Neuronal Function. Endocrinology 2009;150:28052812.

12 Panwar S, Herrid M, Kauter KG, McFarlane JR: Effect of passive immunization against leptin on ovarian follicular development in prepubertal mice. J Reprod Immunol 2012;96:19-24.

13 Dupuis L, Schuermann Y, Cohen T, Siddappa D, Kalaiselvanraja A, Pansera M, Bordignon V, Duggavathi R: Role of leptin receptors in granulosa cells during ovulation. Reproduction 2013;147:221-229.

14 Herrid M, Nguyen VL, Hinch G, McFarlane JR: Leptin has concentration and stage-dependent effects on embryonic development in vitro. Reproduction 2006;132:247-256.

15 Ryan NK, Woodhouse CM, Van der Hoek KH, Gilchrist RB, Armstrong DT, Norman RJ: Expression of Leptin and Its Receptor in the Murine Ovary: Possible Role in the Regulation of Oocyte Maturation. Biol Reprod 2002;66:1548-1554.

16 Kloek C, Haq AK, Dunn SL, Lavery HJ, Banks AS, Myers MG: Regulation of Jak kinases by intracellular leptin receptor sequences. J Biol Chem 2002;277:41547-41555.

17 Banks AS, Davis SM, Bates SH, Myers MG: Activation of downstream signals by the long form of the leptin receptor. J Biol Chem 2000;275:14563-14572.

18 Mütze J, Roth J, Gerstberger R, Hübschle T: Nuclear translocation of the transcription factor STAT5 in the rat brain after systemic leptin administration. Neurosci Lett 2007;417:286-291.

19 Bjørbæk C, Lavery HJ, Bates SH, Olson RK, Davis SM, Flier JS, Myers MG: SOCS3 Mediates Feedback Inhibition of the Leptin Receptor via Tyr ${ }^{985}$. J Biol Chem 2000;275:40649-40657.

20 Zabolotny JM, Bence-Hanulec KK, Stricker-Krongrad A, Haj F, Wang Y, Minokoshi Y, Kim YB, Elmquist JK, Tartaglia LA, Kahn BB, Neel BG: PTP1B regulates leptin signal transduction in vivo. Dev Cell 2002;2:489495.

21 Sugiura K, Pendola FL, Eppig JJ: Oocyte control of metabolic cooperativity between oocytes and companion granulosa cells: energy metabolism. Dev Biol 2005;279:20-30.

22 Dumesic DA, Meldrum DR, Katz-Jaffe MG, Krisher RL, Schoolcraft WB: Oocyte environment: follicular fluid and cumulus cells are critical for oocyte health. Fertil Steril 2015;103:303-316.

23 Russell DL, Gilchrist RB, Brown HM, Thompson JG: Bidirectional communication between cumulus cells and the oocyte: Old hands and new players? Theriogenology 2016;86:62-68.

24 Vigone G, Merico V, Prigione A, Mulas F, Sacchi L, Gabetta M, Bellazzi R, Redi CA, Mazzini G, Adjaye J, Garagna S, Zuccotti M: Transcriptome based identification of mouse cumulus cell markers that predict the developmental competence of their enclosed antral oocytes. BMC Genomics 2013;14:380.

25 Uyar A, Torrealday S, Seli E: Cumulus and granulosa cell markers of oocyte and embryo quality. Fertil Steril 2013;99:979-997. 


\section{Cellular Physiology Cell Physiol Biochem 2020;54:417-437 \begin{tabular}{l|l|l}
\hline DOI: 10.33594/000000228 & ( 2020 The Author(s). Published by
\end{tabular} and BIOChemistry Published online: 30 April $2020 \quad$ Cell Physiol Biochem Press GmbH\&Co. KG \\ Wołodko et al.: Obesity-Induced Leptin Resistance Results in Altered Transcription in \\ Cumulus Cells}

26 Kyrönlahti A, Vetter M, Euler R, Bielinska M, Jay PY, Anttonen M, Heihinheimo M, Wilson DB: GATA4 Deficiency Impairs Ovarian Function in Adult Mice. Biol Reprod 2011;84:1033-1044.

27 Couse JF, Yates MM, Rodriguez KF, Johnson JA, Poirier D, Korach KS: The Intraovarian Actions of Estrogen Receptor- $\alpha$ Are Necessary to Repress the Formation of Morphological and Functional Leydig-Like Cells in the Female Gonad. Endocrinology 2006;147:3666-3678.

28 Koressaar T, Remm M: Enhancements and modifications of primer design program Primer3. Bioinformatics 2007;23:1289-1291.

29 Galvão A, Wolodko K, Rebordão MR, Skarzynski D, Ferreira-Dias G: TGFB1 modulates in vitro secretory activity and viability of equine luteal cells. Cytokine 2018;110:316-327.

30 Zhao S, Fernald RD: Comprehensive Algorithm for Quantitative Real-Time Polymerase Chain Reaction. J Comput Biol 2005;12:1047-1064.

31 Picelli S, Björklund ÅK, Faridani OR, Sagasser S, Winberg G, Sandberg R: Smart-seq2 for sensitive full-length transcriptome profiling in single cells. Nat Methods 2013;10:1096-1098.

32 Picelli S, Faridani OR, Björklund ÅK, Winberg G, Sagasser S, Sandberg R: Full-length RNA-seq from single cells using Smart-seq2. Nat Protoc 2014;9:171-181.

33 Love MI, Huber W, Anders S: Moderated estimation of fold change and dispersion for RNA-seq data with DESeq2. Genome Biol 2014;15:550.

34 Duan J, Choi Y-H, Hartzell D, Della-Fera MA, Hamrick M, Baile CA: Effects of Subcutaneous Leptin Injections on Hypo-thalamic Gene Profiles in Lean and ob/ob Mice. Obesity 2007;15:2624-2633.

35 Eden E, Lipson D, Yogev S, Yakhini Z: Discovering Motifs in Ranked Lists of DNA Sequences. PLoS Comput Biol 2007;3:e39.

36 Eden E, Navon R, Steinfeld I, Lipson D, Yakhini Z: GOrilla: a tool for discovery and visualization of enriched GO terms in ranked gene lists. BMC Bioinformatics 2009;10:48.

37 Assou S, Haouzi D, Mahmoud K, Aouacheria A, Guillemin Y, Pantesco V, Reme T, Dechaud H, De Vos J, Hamamah S: A non-invasive test for assessing embryo potential by gene expression profiles of human cumulus cells: a proof of concept study. Mol Hum Reprod 2008;14:711-719.

38 Gebhardt KM, Feil DK, Dunning KR, Lane M, Russell DL: Human cumulus cell gene expression as a biomarker of pregnancy outcome after single embryo transfer. Fertil Steril 2011;96:47-52.

39 Assou S, Haouzi D, De Vos J, Hamamah S: Human cumulus cells as biomarkers for embryo and pregnancy outcomes. Mol Hum Reprod 2010;16:531-538.

40 Iikuni N, Lam QLK, Lu L, Matarese G, La Cava A: Leptin and Inflammation. Curr Immunol Rev 2008;4:70-79.

41 Faggioni R, Fantuzzi G, Fuller J, Dinarello CA, Feingold KR, Grunfeld C: IL-1 $\beta$ mediates leptin induction during inflammation. Am J Physiol Integr Comp Physiol 1998;274:R204-R208.

42 Fantuzzi G, Faggioni R: Leptin in the regulation of immunity, inflammation, and hematopoiesis. J Leukoc Biol 2000;68:437-446.

43 Cetica P, Pintos L, Dalvit G, Beconi M: Activity of key enzymes involved in glucose and triglyceride catabolism during bovine oocyte maturation in vitro. Reproduction 2002;124:675-681.

44 Thompson JG, Lane M, Gilchrist RB: Metabolism of the bovine cumulus-oocyte complex and influence on subsequent developmental competence. Soc Reprod Fertil Suppl 2007;64:179-190.

45 Sutton-McDowall ML, Gilchrist RB, Thompson JG: The pivotal role of glucose metabolism in determining oocyte developmental competence. Reproduction 2010;139:685-695.

46 Yamagishi S, Edelstein D, Du X, Kaneda Y, Guzmán M, Brownlee M: Leptin Induces Mitochondrial Superoxide Production and Monocyte Chemoattractant Protein-1 Expression in Aortic Endothelial Cells by Increasing Fatty Acid Oxidation via Protein Kinase A. J Biol Chem 2001;276:25096-25100.

47 Unger RH, Zhou YT, Orci L: Regulation of fatty acid homeostasis in cells: novel role of leptin. Proc Natl Acad Sci U S A 1999;96:2327-2332.

48 Wu LLY, Dunning KR, Yang X, Russell DL, Lane M, Norman RJ, Robker RL: High-Fat Diet Causes Lipotoxicity Responses in Cumulus-Oocyte Complexes and Decreased Fertilization Rates. Endocrinology 2010;151:5438-5445.

49 Münzberg H, Flier JS, Bjørbæk C: Region-Specific Leptin Resistance within the Hypothalamus of DietInduced Obese Mice. Endocrinology 2004;145:4880-4889.

50 Brabant G, Müller G, Horn R, Anderwald C, Roden M, Nave H: Hepatic leptin signaling in obesity. FASEB J 2005;19:1048-1050. 


\section{Cellular Physiology Cell Physiol Biochem 2020;54:417-437 \begin{tabular}{l|l|l} 
DOI: 10.33594/000000228 & ( 2020 The Author(s). Published by
\end{tabular} \\ Wołodko et al.: Obesity-Induced Leptin Resistance Results in Altered Transcription in \\ Cumulus Cells}

51 Morgan DA, Thedens DR, Weiss R, Rahmouni K: Mechanisms mediating renal sympathetic activation to leptin in obesity. Am J Physiol Integr Comp Physiol 2008;295:R1730-R1736.

52 Mark AL, Correia MLG, Rahmouni K, Haynes WG: Selective leptin resistance: a new concept in leptin physiology with cardiovascular implications. J Hypertens 2002;20:1245-1250.

53 Joo JK, Joo BS, Kim SC, Choi JR, Park SH, Lee KS: Role of leptin in improvement of oocyte quality by regulation of ovarian angiogenesis. Anim Reprod Sci 2010;119:329-334.

54 Bouilly J, Sonigo C, Auffret J, Gibori G: Prolactin signaling mechanisms in ovary. Mol Cell Endocrinol 2012;356:80-87.

55 Fernández-Riejos P, Najib S, Santos-Alvarez J, Martín-Romero C, Pérez-Pérez A, González-Yanes C, SanchezMargalet V: Role of Leptin in the Activation of Immune Cells. Mediators Inflamm 2010;2010:568343.

56 Skaznik-Wikiel ME, Swindle DC, Allshouse AA, Polotsky AJ, McManaman JL: High-Fat Diet Causes Subfertility and Compromised Ovarian Function Independent of Obesity in Mice. Biol Reprod 2016;94:108.

57 Pelkmans L, Fava E, Grabner H, Hannus M, Habermann B, Krausz E, Zerial M: Genome-wide analysis of human kinases in clathrin- and caveolae/raft-mediated endocytosis. Nature 2005;436:78-86.

58 Giridharan SSP, Cai B, Vitale N, Naslavsky N, Caplan S: Cooperation of MICAL-L1, syndapin2, and phosphatidic acid in tubular recycling endosome biogenesis. Mol Biol Cell 2013;24:1776-1790.

59 Wang Y: Small lipid-binding proteins in regulating endothelial and vascular functions: focusing on adipocyte fatty acid binding protein and lipocalin-2. Br J Pharmacol 2012;165:603-621.

60 Günzel D, Yu ASL: Claudins and the modulation of tight junction permeability. Physiol Rev 2013;93:525569.

61 Mirsaeidi M, Gidfar S, Vu A, Schraufnagel D: Annexins family: insights into their functions and potential role in pathogenesis of sarcoidosis. J Transl Med 2016;14:89.

62 Vanorny DA, Mayo KE: The role of Notch signaling in the mammalian ovary. Reproduction 2017;153:R187R204.

63 Albertini DF, Combelles CM, Benecchi E, Carabatsos MJ: Cellular basis for paracrine regulation of ovarian follicle development. Reproduction 2001;121:647-653.

64 Li R, Albertini DF: The road to maturation: somatic cell interaction and self-organization of the mammalian oocyte. Nat Rev Mol Cell Biol 2013;14:141-152.

65 Liu Z, de Matos DG, Fan HY, Shimada M, Palmer S, Richards JS: Interleukin-6: An Autocrine Regulator of the Mouse Cumulus Cell-Oocyte Complex Expansion Process. Endocrinology 2009;150:3360-3368.

66 Vaisberg EA, Grissom PM, McIntosh JR: Mammalian cells express three distinct dynein heavy chains that are localized to different cytoplasmic organelles. J Cell Biol 1996;133:831-842.

67 Tripal P, Bauer M, Naschberger E, Mörtinger T, Hohenadl C, Cornali E, Thurau M, Sturzl M: Unique Features of Different Members of the Human Guanylate-Binding Protein Family. J Interf Cytokine Res 2007;27:44-52.

68 Tao W, Pennica D, Xu L, Kalejta RF, Levine AJ: Wrch-1, a novel member of the Rho gene family that is regulated by Wnt-1. Genes Dev 2001;15:1796-1807.

69 Bilbao MG, Di Yorio MP, Faletti AG: Different levels of leptin regulate different target enzymes involved in progesterone synthesis. Fertil Steril 2013;99:1460-1466.

70 Di Yorio MP, Bilbao MG, Pustovrh MC, Prestifilippo JP, Faletti AG: Leptin modulates the expression of its receptors in the hypothalamic-pituitary-ovarian axis in a differential way. J Endocrinol 2008;198:355-366.

71 Yang WH, Liu SC, Tsai CH, Fong YC, Wang SJ, Chang YS, Tang CH: Leptin Induces IL-6 Expression through OBRl Receptor Signaling Pathway in Human Synovial Fibroblasts. PLoS One 2013;8:e75551.

72 Loffreda S, Yang SQ Lin HZ, Karp CL, Brengman ML, Wang DJ, Klein AS, Bulkley GB, Bao C, Noble PW, Lane MD, Diehl AM: Leptin regulates proinflammatory immune responses. FASEB J 1998;12:57-65. 